\title{
MEXICANOS POR NATURALIZACIÓN EN LA PRIMERA MITAD DEL SIGLO XX. UN ACERCAMIENTO CUANTITATIVO
}

\author{
Pablo Yankelevich ${ }^{1}$ \\ El Colegio de México
}

¿ uántas cartas de naturalización fueron expedidas en México a lo largo de la historia nacional? La Secretaría de Relaciones Exteriores es la dependencia encargada de estos asuntos y si en búsqueda de respuesta cualquier interesado acude al Comité de Información de esta Secretaría obtendrá como contestación una "declaratoria de inexistencia de información.” Sucede que la Secretaría de Relaciones

Fecha de recepción: 27 de mayo de 2014

Fecha de aceptación: 16 de junio de 2014

${ }^{1}$ Dejo constancia de mi agradecimiento a Erika Pani, Daniela Gleizer, Juan Pedro Viqueira, Manuel Ángel Castillo y Manuel Ordorica por la ayuda y recomendaciones para la realización de este trabajo. De manera particular agradezco a Graciela Márquez su generoso auxilio en el diseño estadístico. Por último, mi gratitud a Efraín Granados, Carlos Carranza, Isis Ledezma y Myriam Olivares por su colaboración en la captura y sistematización de la información. Este trabajo se realizó en el marco del Proyecto Conacyt CB 2010-151011-H y del Proyecto Colmex-Promep PTC 039. 
Exteriores dispone de series estadísticas sobre nacionalidad y naturalización sólo a partir de 2007.2

Las normas que atribuyen la nacionalidad y las prácticas que la conceden son los dispositivos que regulan la pertenencia de un individuo a una comunidad nacional. Resulta llamativo que en una nación como México, con una legislación marcadamente prescriptiva respecto a los deberes y derechos de los extranjeros, el Estado carezca de una cuantificación de los extranjeros que dejaron de serlo para convertirse en mexicanos por naturalización. Si hasta fechas muy recientes no existían series históricas sobre extranjeros naturalizados y tampoco estadísticas históricas sobre inmigración ${ }^{3}$ entonces, ¿sobre qué bases se tomaban decisiones políticas acerca de estos asuntos? Es difícil saberlo. Se puede suponer que debieron existir algunos insumos y que no se han conservado en los archivos de las dependencias oficiales. También es posible suponer que muchas decisiones estuvieron fundadas más en percepciones e imaginarios en torno de la extranjería que en soportes cuantitativos sobre volúmenes y características de las corrientes de extranjeros que residieron en México y que en algún momento optaron por la naturalización. La invisibilidad estadística de los extranjeros naturalizados en México es notoria; los censos generales de población desde 1950 dejaron de registrarlos. Por otra parte, no siempre

2 SRE. Comité de Información, Oficio CI-110, folio 0000500018114 , México, DF, 24 de febrero de 2014.

${ }^{3}$ La Secretaría de Gobernación dispone de series históricas sobre inmigración a partir de 1991. Véase http://www.gobernacion.gob.mx/es_mx/ SEGOB/Series_Historicas Para una aproximación al universo de las fuentes cuantitativas para el estudio de los extranjeros en México, véase Rodríguez Chávez, "Fuentes”. 
se ha asentado el país de nacimiento junto a la nacionalidad de los nacidos en el extranjero, situación que ha dificultado ponderar la real dimensión de los extranjeros en la población nacional, tal y como lo ha demostrado Manuel Ángel Castillo en un reciente estudio sobre los censos de 2000 y $2010 .{ }^{4}$

Esta situación no ha sido un obstáculo para legislar en estos asuntos, por el contrario, a lo largo de los siglos xix y $\mathrm{xx}$ la nacionalidad ha sido motivo de muchos debates que cristalizaron en abigarrados marcos normativos. Durante el siglo XIX, fueron promulgadas seis leyes sobre extranjería y naturalización; la última fue la Ley Vallarta de 1886 que recogió parte de la experiencia acumulada en la materia y que reguló el principio del ius sanguinis proclamado en la Constitución de 1857. En los hechos se trató de una ley que reglamentó el artículo 30 de aquella Constitución precisando circunstancias, requisitos y procedimientos para que una persona fuera considerada mexicana o extranjera. Ignacio Vallarta justificó esta ley en el liberal principio de que sólo en la libre decisión del individuo podía fundarse el cambio de nacionalidad. Es decir, la obtención de la nacionalidad no podía estar sujeta a la contingencia del lugar donde se nace sino a una voluntad libremente expresada. A pesar de ello, esta ley, en concordancia con el artículo 30 constitucional, reglamentó un mecanismo de naturalización automática para todos los extranjeros propietarios de bienes raíces y para los que tuvieran hijos nacidos en el país. ${ }^{5}$ ¿Cuál era el

\footnotetext{
${ }^{4}$ Castillo, "Extranjeros en México".

${ }^{5}$ El artículo 30 de la Constitución de 1857 estableció que son mexicanos los nacidos dentro o fuera del país de padres mexicanos, los extranjeros naturalizados, y los extranjeros que adquieran bienes raíces o tengan hijos nacidos en el país, "siempre que no manifiesten su voluntad de
} 
sentido de naturalizar de oficio a estos extranjeros? En realidad se buscó una herramienta para guarecerse de reclamos internacionales que pudieran conducir a conflictos bélicos como los que ya había soportado el país. Es decir, mediante esa disposición se colocaba a propiedades de extranjeros y a sus herederos bajo soberanía nacional evitando que invocaran la protección de sus gobiernos para defender su patrimonio. Erika Pani, después de estudiar la legislación sobre naturalización en el siglo xIx mexicano, concluyó que estas normas apuntaban a "consolidar las capacidades de control de un Estado débil, más que a fundamentar los derechos políticos de nuevos ciudadanos”. ${ }^{6}$ Quizá no haya mejor ejemplo de esta manera de procesar la naturalización que el hecho de que sea la Secretaría de Relaciones Exteriores la agencia responsable de otorgarla. A diferencia de la mayoría de las naciones, en México estos asuntos son materia de política exterior en lugar de ser considerados ámbitos de la política de población y migración bajo la responsabilidad de la Secretaría de Gobernación, tal y como ha sido observado por expertos en materia de derecho internacional privado. ${ }^{7}$

Si a lo largo del siglo xix los extranjeros residentes en México fueron valorados como un riesgo, la revolución de 1910 reforzó esta percepción en grado extremo. El robusto nacionalismo en los discursos y en las prácticas de los revolucionarios durante la contienda armada cristalizó en un

conservar su nacionalidad". Cámara de Diputados, Derechos, p. 678. El último párrafo del artículo 30 constitucional quedó regulado en la Ley de Extranjería y Naturalización de 1886 en los incisos 10 y 11 del artículo 1 y en el artículo 19. INM, Compilación, pp. 94 y 98.

6 PANI, "Ciudadanos precarios", p. 638.

7 Carrillo, "La postura”, p. 396. 
ordenamiento constitucional que instituyó una serie de salvaguardas en favor de los mexicanos. ${ }^{8}$ Prerrogativas en materia de derechos de propiedad y en cuestiones políticas tendieron un cinturón defensivo alrededor de los nacionales haciendo evidente que la extranjería constituía un problema que merecía particular atención.

El asunto a enfrentar no era sólo deberes y obligaciones de los extranjeros, sino definir quién era mexicano por nacimiento y quién por naturalización. Los juristas que elaboraron el proyecto constitucional que presentó Venustiano Carranza advirtieron la inconsistencia que introdujo la Constitución de 1857 y que reprodujo la ley de 1886. Por ello, ateniéndose en sentido estricto al ius sanguinis propusieron que "son mexicanos por nacimiento los hijos de padres mexicanos que nacieran dentro o fuera del territorio nacional, mientras

${ }^{8}$ El artículo 8 de la Constitución de 1917 excluyó a los extranjeros del derecho de petición en materia política; el artículo 9 hizo lo propio respecto de los derechos de reunión y asociación; el artículo 11 estableció que la libertad de tránsito estaría regulada por las leyes migratorias; el 27 limitó los derechos de propiedad; el 32 estableció un régimen jurídico preferente en favor de los mexicanos y el 33 prohibió a los extranjeros inmiscuirse en asuntos políticos, estipulando que todo extranjero cuya presencia fuera juzgada inconveniente podía ser expulsado del país de manera inmediata y sin necesidad de juicio previo. Por otro lado, en materia de derechos políticos, los mexicanos por naturalización fueron excluidos del derecho a ocupar puestos de elección popular (diputados, senadores y gobernadores, artículos 55, 59 y 115), y para desempeñar algunas posiciones de la administración federal (secretarios de Estado, magistrados de la Suprema Corte de Justicia y procurador general de Justicia, artículos 91, 95 y 102). Entre las condiciones para ocupar la presidencia de la República, se instituyó el requisito de ser mexicano por nacimiento e hijo de padres mexicanos por nacimiento (artículo 82). Por último, el artículo 130 estableció que sólo los mexicanos por nacimiento podrían desempeñarse como ministros de cualquier culto religioso (Constitución). 
que los extranjeros y sus hijos sólo podían adquirir la nacionalidad mediante un procedimiento administrativo, por tanto serían considerados mexicanos por naturalización". 9 Los resguardos ante los peligros que podían representar propiedades en manos extranjeras habían sido contemplados en otros artículos constitucionales, de manera que el apego al derecho de filiación no alentaría reclamos internacionales y quitaba, por otra parte, la ambigüedad en la definición de la nacionalidad. Sin embargo, no fue este el criterio que terminó consagrando la Constitución de 1917, sino una extraña fórmula que combinó el ius sanguinis para hijos de padres mexicanos y el ius soli para hijos de padres extranjeros. ${ }^{10}$ Se trató de un mecanismo que convertía en mexicanos por nacimiento a personas mayores de edad nacidas como extranjeras. A lo largo de casi dos décadas se debatió este asunto en vanos intentos por reglamentar la fórmula sancionada en el artículo 30 . La desconfianza que despertaba la extranjería atravesó discusiones y proyectos legislativos que entre otros asuntos buscaban certidumbre sobre el momento más apropiado para que se concediera la nacionalidad mexicana a una persona nacida en México como extranjera. ${ }^{11}$

9 Cámara de Diputados, Derechos, p. 679.

10 El artículo 30 de la Constitución de 1917 estipuló que "Son mexicanos por nacimiento los hijos de padres mexicanos nacidos dentro o fuera de la República, siempre que en este último caso los padres sean mexicanos por nacimiento. Se reputan mexicanos por nacimiento los que nazcan en la República de padres extranjeros, si dentro del año siguiente a su mayor edad manifiestan ante la Secretaría de Relaciones Exteriores que optan por la nacionalidad mexicana y comprueban ante aquélla que han residido en el país los últimos seis años anteriores a dicha manifestación”. Diario Oficial de la Federación (5 feb. 1917), p. 152.

11 AHDSRE, 10-4-14, f. 56. 
Entre tanto y a falta de otra reglamentación, continuó vigente la ley de 1886, a pesar de que ella no contemplaba los cambios que había introducido la Constitución de 1917, y tampoco los requerimientos que nuevas leyes de migración imponían a extranjeros residentes en México. Es decir, a lo largo de casi dos décadas, los trámites de naturalización estuvieron sin una reglamentación ajustada a las disposiciones constitucionales y a una nueva realidad migratoria. Finalmente, en los albores del cardenismo fue aprobada una nueva Ley de Nacionalidad y Naturalización; en ella se adoptó del principio del ius soli, manteniendo el ius sanguinis, para hijos de mexicanos nacidos en el extranjero. Desde 1934 todos los nacidos en territorio nacional son considerados mexicanos por nacimiento con independencia de la nacionalidad de los padres. La adopción del ius soli partió de un reconocimiento de que el ius sanguini había constituido "una directiva inadecuada a nuestro medio”. ${ }^{12}$ ¿Dónde radicó la inadecuación? Sucedía que al amparo del derecho de filiación se continuaba alimentando el "privilegio" de ser extranjero. Los hijos de extranjeros nacidos en México, en lugar de hacer uso del derecho a ser "mexicanos por nacimiento", preferían mantener su condición de extranjeros y por ello se atrincheraban "en la defensa de derechos que creen tener, siendo indiferentes a los progresos de orden social y político y un verdadero obstáculo cuando esos progresos significan un sacrificio material". ${ }^{13}$ El ius soli fue adoptado para corregir una estrategia que mostró su fracaso. Se trataba de recortar "privilegios” por la vía de la naturalización. De esta forma y como en toda

12 AHDSRE, 10-4-14, f. 152.

13 AHDSRE, 10-4-14, f. 153. 
la legislación decimonónica, la concesión de la nacionalidad a extranjeros tampoco fue inspirada en la voluntad de ampliar la soberanía política de la nación; al contrario, volvía a fundarse en la necesidad de liquidar una situación de preeminencia que se transmitía de generación en generación.

Los debates en torno del ius soli y el ius sanguinis traslucen los recelos con que fue procesada la extranjería en México, y esa atmósfera de prevenciones impactó en requisitos y trámites para que un extranjero se convirtiera en mexicano por naturalización. La ley de 1934, en comparación con la de 1886, complicó de manera sustancial las exigencias y el recorrido administrativo. Para comenzar, el periodo de residencia mínima para optar por la nacionalidad fue elevado de dos a cinco años. En ambas leyes, el Poder Judicial participaba como verificador de los antecedentes del extranjero, para después solicitar al Poder Ejecutivo la expedición de la carta de naturalización. La Secretaría de Relaciones Exteriores tenía la potestad de conceder la nacionalidad; en este sentido, la naturalización se adquiría por una dispensa política. Como ha indicado Pani, en realidad se trata de un acto de gracia y no de justicia. ${ }^{14}$

Con anterioridad a 1934 el trámite se iniciaba ante un ayuntamiento cuando el extranjero manifestaba su voluntad de adquirir la nacionalidad mexicana; después debía acudir a un juzgado y los únicos requisitos, además del periodo de residencia mínima, fueron haber observado buena conducta y demostrar un modo honesto de vivir. A partir de la nueva ley, la gestión dejó de lado la instancia municipal. Comenzaba con una manifestación ante la Secretaría de Relaciones

${ }^{14}$ PANI, "Hacer propio", p. 361. 
Exteriores y tenía como requisito básico la certificación por autoridades locales de que el extranjero tuviera un mínimo de dos años de residencia ininterrumpida en el país. Además, este primer expediente debía contener un certificado de legal estancia expedido por las autoridades migratorias, un certificado de buena salud, un comprobante de tener 18 años o más de edad, cuatro retratos fotográficos y una declaración en que constara la última residencia que tuvo el extranjero antes de ingresar al país. Tres años después de realizado el primer trámite, siempre y cuando no hubiera interrumpido su residencia en el país, el interesado debía acudir ante un juez de distrito y solicitar la carta de naturalización. El extranjero debía probar que había vivido en el país ininterrumpidamente durante cinco años, que había observado buena conducta, que tenía manera honesta de vivir, que sabía hablar español, que gozaba de buena salud y que estaba al corriente del pago de impuestos. Una vez integrado el expediente, el juez daba aviso a la Secretaría de Relaciones Exteriores y ésta ordenaba la publicación en el Diario Oficial de la Federación y en un periódico de circulación nacional de un extracto del trámite de solicitud. Sólo entonces el juez, en concurrencia con el Ministerio Público, analizaría las pruebas ofrecidas por el extranjero y si a juicio de estas autoridades la documentación acreditaba los requisitos exigidos, el interesado debía por intermedio del juez elevar una solicitud de carta de naturalización y acompañar esta solicitud con una renuncia expresa a "toda sumisión, obediencia y fidelidad a cualquier gobierno extranjero, especialmente de quien el solicitante hay sido súbdito". ${ }^{15}$

15 AHDSRE, 10-4-14, ff. 68-71. 
Por otro lado, la ley de 1934 introdujo un cambio importante en el caso de las mujeres. Hasta esa fecha, las mujeres casadas mexicanas y extranjeras perdían la nacionalidad de origen para adoptar la de sus esposos. La ley de 1934 instituyó la igualdad jurídica entre cónyuges siempre y cuando la mujer fuera mexicana. Es decir, el matrimonio como instancia de atribución de nacionalidad funcionó de manera diferenciada para las mexicanas y para las extranjeras. Las mexicanas casadas con extranjero ya no perdían su nacionalidad, mientras que sí la perdían las mujeres extranjeras casadas con mexicano. En este último caso, la voluntad nacionalizadora de la ley convertía de manera automática en nacional a toda extranjera unida en matrimonio con un mexicano. ${ }^{16}$

La ley de 1934, en atención a las disposiciones que desde el siglo xix habían enredado los trámites de naturalización, sobre todo en los casos de propiedades en manos de extranjeros, terminó habilitando una ancha vía "extraordinaria” para acceder a la nacionalidad mexicana siempre que se cumplieran requisitos como tener establecido en territorio nacional industria, empresa o negocio de beneficio social; tener hijos legítimos nacidos en México; ser colono radicado en el país, ser "indolatino" con residencia en la República, entre otros. ${ }^{17}$ El cumplimiento de alguna de estas condiciones permitía al solicitante iniciar un trámite de "naturalización privilegiada" que lo exentaba del requisito de acudir ante el Poder Judicial. En realidad el privilegio consistía en que las gestiones podín realizarse directamente en la Secretaría de Relaciones Exte-

16 "Ley de Nacionalidad y Naturalización”, Diario Oficial de la Federación (20 ene. 1934), p. 238.

17 AHDSRE, 10-4-14, f. 72. 
riores, y en algunos casos el requisito de residencia disminuía a dos años. ${ }^{18}$

A partir de estos antecedentes, el presente trabajo indaga la dimensión cuantitativa de la política de naturalización en México durante la primera mitad del siglo xx. ¿Cuántos extranjeros se naturalizaron y cuáles fueron sus orígenes nacionales? ¿Cuál su distribución por sexo, por estado civil, lugar de residencia y ocupación? ¿Hubo regímenes de excepción en el otorgamiento de la nacionalidad mexicana que permitieron engrosar los volúmenes de naturalizados? ¿Es posible encontrar alguna correlación entre nuevos flujos inmigratorios y el comportamiento de las naturalizaciones? ¿De qué manera impactaron en las naturalizaciones los cambios en la legislación sobre migración y extranjería? Estos interrogantes, entre otros, guiaron una investigación interesada en cuantificar el universo de extranjeros naturalizados a lo largo de unas décadas en que, a pesar del fuerte nacionalismo que impulsó las políticas de extranjería más restrictivas que conoció el país, se registraron los más altos índices de naturalización hasta inicios de la presente centuria.

\section{ANTECEDENTES Y FUENTES}

Desde un punto de vista cuantitativo no abundan estudios sobre extranjeros naturalizados. Dos son los antecedentes más lejanos, el primero es el clásico estudio de Gilberto Loyo sobre la política demográfica en México publicado en 1935. En un pequeño apartado, Loyo analizó el aporte de los natu-

18 "Ley de Nacionalidad y Naturalización”, Diario Oficial de la Federación (20 ene. 1934), p. 239. 
ralizados a la población nacional en el quinquenio 1929-1933 exhibiendo cifras totales por año y desagregados por nación de origen y ocupación. No hay referencia a las fuentes usadas para estos cálculos aunque se puede inferir que provienen de los Anuarios de la Dirección de Estadística Nacional y del Censo de Población de 1930. ${ }^{19}$ El segundo antecedente es la referencia a las naturalizaciones registradas en México entre 1828 y 1953 que hizo Julio Durán Ochoa en una investigación publicada en 1955. Esta es la primera noticia de una serie completa de naturalizaciones de más de 100 años. Este autor sólo ofrece cifras totales desagregadas por países de origen. ${ }^{20}$ No hay mención de la fuente utilizada aunque los datos provienen de la Secretaría de Relaciones Exteriores, como se expondrá más adelante.

El tema no volvió a ser objeto de análisis hasta la publicación en 2013 de un artículo de Theresa Alfaro Vercamp. ${ }^{21}$ Con información proveniente de la Secretaría de Relaciones Exteriores y en el marco de una preocupación centrada en las políticas de indeseabilidad hacia la inmigración, la autora realizó una aproximación cuantitativa de lo sucedido entre 1913 y 1931 a la que agregó los años de 1936 y 1937. Por primera vez se ofrece una mirada que articula volúmenes anuales, nacionalidades y lugares de residencia en México dibujando algunas tendencias del comportamiento de las prácticas de naturalización en el periodo de referencia. Sin embargo, las series no fueron consultadas completas, situación que impide entre otras cuestiones valorar la trayectoria de las natura-

${ }_{19}$ Loyo, La política demográfica, pp. 348-350.

20 Durán Ochoa, Estructura económica, pp. 164-166.

${ }^{21}$ Alfaro-Velcamp, "When Pernicious”. 
lizaciones durante los años treinta, justamente el periodo en que aumentaron las restricciones migratorias al punto de que México prácticamente cerró sus puertas, con la excepción del masivo arribo de exilados republicanos españoles.

Por otro lado, en un reciente estudio, Daniela Gleizer arroja luz sobre las causas de rechazo a solicitudes de naturalización entre 1928 y $1934 .^{22}$ Este trabajo incluye un apartado cuantitativo que se funda en una muestra aleatoria de una serie documental resguardada en la Secretaría de Relaciones Exteriores y que concentra exclusivamente los trámites que no concluyeron satisfactoriamente. Es decir, se trata de una serie donde los expedientes combinan trámites denegados con trámites que los solicitantes abandonaron de manera voluntaria en alguna etapa de la gestión. Las cifras que muestra Gleizer son estimaciones que, con las reservas del caso, permiten acercarse a un aproximado de solicitudes rechazadas durante el sexenio indicado. Por último, Erika Pani, en una investigación de largo alcance orientada al estudio de los vínculos entre extranjería y construcción de la ciudadanía en el siglo XIX mexicano, dedica un capítulo a las cifras de la naturalización en aquella centuria. Las fuentes para este trabajo también fueron localizadas en Relaciones Exteriores y a partir de ellas se trazan los perfiles sociodemográficos del total de naturalizaciones entre 1828 y 1917 . Este es el estudio sociodemográfico más acabado sobre naturalizaciones en México y los resultados que exhibe constituyen un sólido antecedente con quien dialoga este artículo. ${ }^{23}$

22 Gleizer, "Los límites".

23 Pani, Para pertenecer. 
Los insumos para una reconstrucción cuantitativa de la política de naturalización en México pueden localizarse, por un lado, en los Censos Generales de Población, en particular los realizados entre 1900 y 1940 por ser, como ya se indicó, los únicos que capturaron información sobre nacionalidad mexicana por adopción. Estos datos, además de fragmentarios y de no estar desagregados por nacionalidad, tienen el inconveniente de medir el stock acumulado decenalmente, situación que impide ponderar el ritmo de las naturalizaciones a lo largo de los decenios. Por otro lado, se encuentra la información contenida en series bibliodocumentales de la Secretaría de Relaciones Exteriores. Estas fuentes son diversas y cada una presenta características que fijan sus limitaciones. Se trata de series editadas en el Boletín Oficial y en las Memorias de Labores de la Secretaría de Relaciones Exteriores. El Boletín contiene información completa entre 1898 y 1913; a partir de este último año fueron publicados de manera intermitente hasta inicios de la década de 1930. Esta serie permite acercarse a algunos periodos de un universo de casi dos siglos con el inconveniente de que la información es parcial puesto que en determinadas épocas se enlistan los nombres de los extranjeros naturalizados, la nacionalidad de origen, el número de carta de naturalización y su fecha de expedición, y otras veces se agrega el lugar de residencia en México y la profesión u oficio. Las Memorias de Labores poseen problemas similares por la irregularidad de su aparición y porque desde la década de 1920 sólo proporcionan los totales anuales de cartas expedidas, sin mayores precisiones.

En realidad, los documentos para un estudio de las naturalizaciones en México están localizados en los archivos de Relaciones Exteriores. El Archivo Histórico Diplomático 
(AHDSRE) resguarda los expedientes desde las primeras décadas del siglo xIx hasta 1980 aproximadamente. Para tiempos más recientes, y no abierta a la consulta pública, la información se encuentra en series y en archivos perteneciente a las distintas dependencias encargadas de los trámites de naturalización. Visto en su conjunto estos acervos concentran la totalidad de expedientes de los trámites de naturalización ordenados en series temáticas (cartas de naturalización, certificados de nacionalidad, ${ }^{24}$ solicitudes, etc.). La consulta de cada expediente permitiría un seguimiento preciso tanto del recorrido del trámite como de las cualidades y características de los solicitantes (nombre, edad, lugares de nacimiento y de residencia, ocupación, estado civil, etc.). Las principales limitaciones de este acervo radica por un lado, en la magnitud del esfuerzo necesario para consultar decenas de millares de expedientes y, por otro, en la prohibición que fija la Ley de Archivos vigente al vetar la consulta de expedientes con menos de 70 años de antigüedad. De esta forma, una investigación que se propusiera la revisión de la totalidad de los expedientes de los fondos de naturalización de la Secretaría de Relaciones Exteriores necesariamente dejaría fuera las últimas siete décadas, sobre las que sólo es posible conocer los totales de cartas de naturalización desagregados por años. ${ }^{25}$

Por último, un importante insumo para el estudio de las naturalizaciones está contenido en tres abultados expedientes

${ }^{24}$ A diferencia de las cartas de naturalización que acreditan que un extranjero ha obtenido la nacionalidad mexicana, los certificados de naturalización son documentos que antes de la adopción del ius soli se otorgaban a los hijos de extranjeros nacidos en el país en el caso de que manifestaran su voluntad de ser mexicanos por nacimiento.

${ }^{25}$ Véase la nota 28. 
reguardados en el AHDSRE. ${ }^{26}$ Se trata de una relación completa de las cartas de naturalización entregadas entre 1828 y 1953. Esta fue la fuente que consultó Durán Ochoa a mediados del siglo pasado y sirvió de base a los trabajos de Alfaro-Vercamp, de Pani y a parte de la investigación de Gleizer. La característica más significativa de estos documentos y que otorga un amplio margen de confiabilidad radica en que incluyen la numeración correlativa de todas las cartas de naturalización entregadas por la cancillería a lo largo de 125 años. Además de los nombres, nacionalidad de origen y fecha de naturalización, en algunos de estos expedientes, y dependiendo de los periodos, los datos se amplían con información sobre el estado civil, lugar de residencia, ocupación o profesión.

Estos tres expedientes constituyen el principal soporte documental de este trabajo. A fin de confirmar la fiabilidad de las cifras que arrojó el procesamiento de esta información, se cotejaron resultados del procesamiento de esta fuente con los datos que arrojan las series de los Boletines y las Memorias de la Secretaría de Relaciones Exteriores y los Censos Generales de Población. Por otra parte, y de manera aleatoria, se consultó el acervo de expedientes personales en el AHDSRE a fin de completar información sobre características sociodemográficas que para determinados periodos no estaban incorporadas en los tres expedientes aludidos. Esta información fue enriquecida con los datos que contiene la serie documental dedicada a las cartas de naturalización de españoles republicanos refugiados entre 1940 y $1944 .^{27}$ El conjunto de esta

${ }_{26}$ AHDSRE, L-E 1992; 26-23-97 y L-E 1993.
27 AHDSRE, L-E 1120 A-K y L-E 1121 L-Z. 
información (1828-1953) fue tabulada a partir de una serie de descriptores que permiten asomarse a los volúmenes anuales de naturalización y a una serie de indicadores del perfil sociodemográfico. Para la segunda mitad del siglo xx y por las razones antes expuestas sólo se presentan los volúmenes anuales. ${ }^{28}$ Como se advertirá, el contraste con lo sucedido en la primera mitad de esa centuria permite recortar el universo específico de naturalizados al que está dedicado este trabajo.

\section{VOLÚMENES Y COMPOSICIÓN}

Entre 1828 y 1999 se naturalizaron en México 36519 extranjeros: $93 \%$ de esas naturalizaciones corresponden al siglo $\mathrm{xx}$ y $75 \%$ se otorgaron entre el final de la etapa armada de la Revolución y comienzos de los años cincuenta. Es decir, alrededor de 27000 personas obtuvieron sus cartas de naturalización entre 1920 y 1953.

Esas primeras décadas de la posrevolución destacan por los volúmenes pero también por la composición de esos extranjeros naturalizados. Entre el regreso al orden constitucional en 1917 y los años posteriores al final de la segunda guerra mundial se asiste a un incremento significativo en los flujos de inmigración. Es sabido que la migración extranjera nunca

${ }^{28}$ Las fuentes usadas para reconstruir los volúmenes anuales de naturalización entre 1954 y 1999 provienen de las Memorias de la Secretaría de Relaciones Exteriores y de la información que proporciona la siguiente página web: www.sre.gob.mx/index.php/-estadisticas-de-documentosart-30-constitucional. Para el periodo 1954-1978, las cifras obtenidas de estas fuentes fueron cotejadas con información procedente de una base de datos de expedientes de naturalización que se encuentra en el AHDSRE. Esta base de datos es una herramienta de consulta que el personal del citado archivo utiliza para la localización de expedientes. 


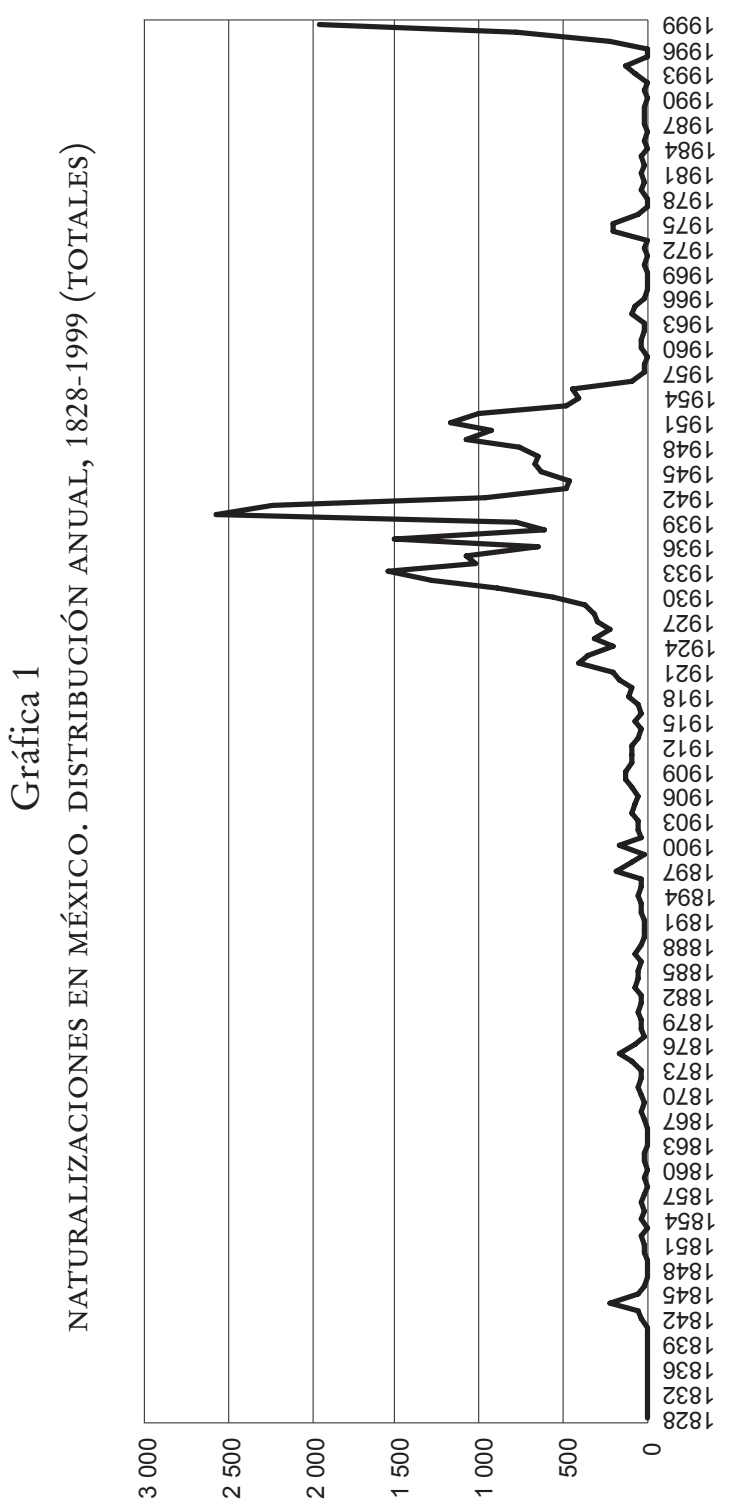


Gráfica 2

DISTRIBUCIÓN DE NATURALIZACIONES. SIGLOS XIX Y XX $\%$

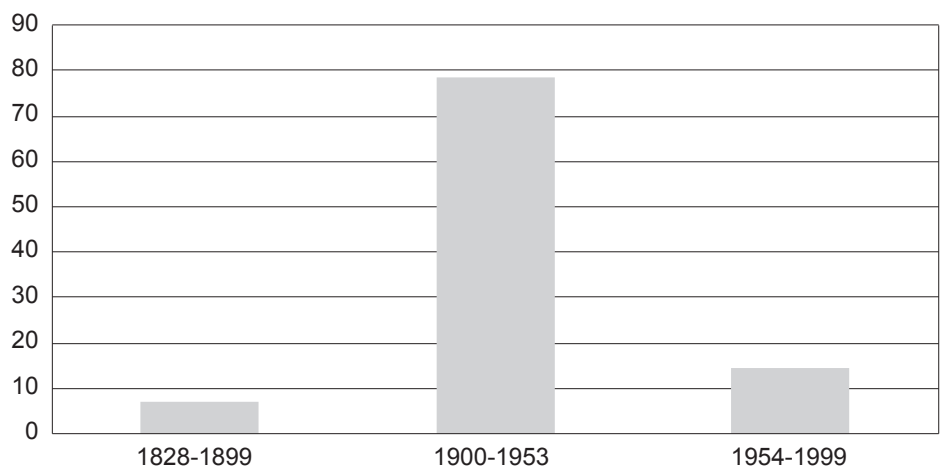

constituyó un afluente significativo de la población nacional. A lo largo de un siglo, los censos de población muestran que el volumen de extranjeros en el total de habitantes osciló entre $0.4 \%$ y $0.9 \%$. México no fue un país de inmigración a pesar del deseo de sus élites dirigentes, pero en el contexto de estas reducidas magnitudes es posible inferir una correlación entre el incremento de corrientes migratorias y las naturalizaciones entre 1920 y 1950.

Entre 1828 y 1953 se naturalizaron algo más de 31000 extranjeros. Al desagregar por nacionalidad estas cifras, resulta mayoritaria la participación de España con casi $41 \%$ de los naturalizados seguida de guatemaltecos con $16 \%$. Si se observan los volúmenes y los orígenes nacionales de las cartas de naturalización, es manifiesta la correspondencia con la trayectoria de las distintas comunidades de inmigrantes en la historia mexicana. Así, por ejemplo, mientras en el siglo XIX 


\section{Gráfica 3}

POBLACIÓN NACIONAL Y EXTRANJERA, 1900-2000 (TOTALES)

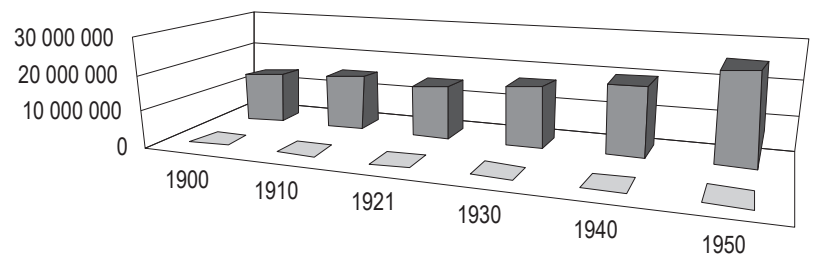

\begin{tabular}{|l|c|c|c|c|c|c|}
\cline { 2 - 7 } \multicolumn{1}{c|}{} & 1900 & 1910 & 1921 & 1930 & 1940 & 1950 \\
\hline$\square$ Población extranjera & 58179 & 116526 & 108080 & 140587 & 177375 & 182707 \\
\hline$\square$ Población nacional & 13549080 & 15043843 & 14226700 & 16412135 & 19476177 & 25608310 \\
\hline
\end{tabular}

\section{Gráfica 4}

PARTICIPACIÓN DE EXTRANJEROS EN LA POBLACIÓN TOTAL,

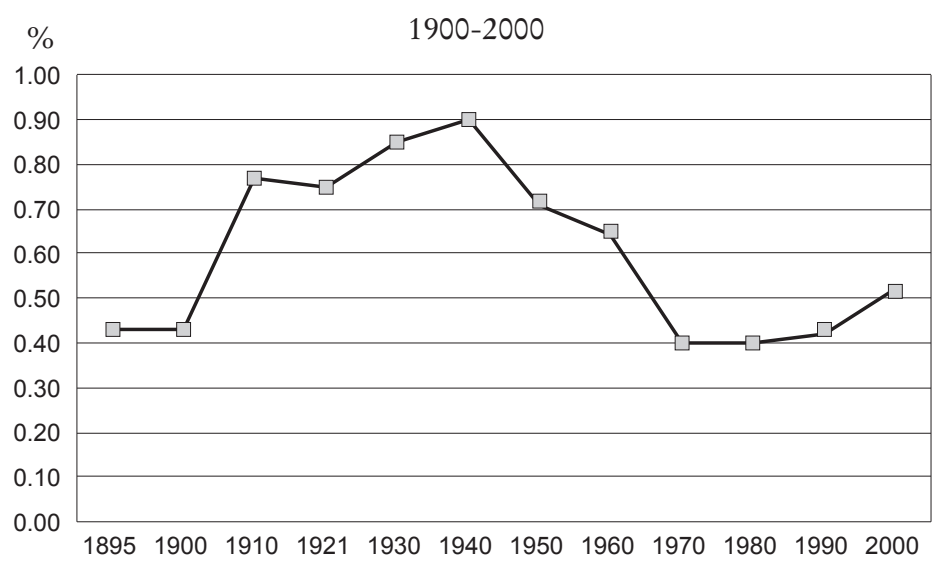

las naturalizaciones corresponden a extranjeros procedentes de Europa occidental y en menor medida de países vecinos y de Asia, en el siglo xx el mapa de las naturalizaciones revela la emergencia de corrientes migratorias nuevas. En estos 125 años (1828-1953) nueve naciones (España, Guatemala, Ale- 
mania, Francia, Italia, Inglaterra, Estados Unidos, China y Cuba) concentraron las tres cuartas partes de las cartas de naturalización. Entre el siglo XIx y el xx la continuidad en algunas nacionalidades revela la permanencia de flujos tradicionales que transitan en buena medida a partir de relaciones comerciales, industriales y financieras que han vinculado a México con Estados Unidos, Inglaterra, Alemania, Francia y España; que denotan la cercanía y los contactos históricos con Guatemala y con Cuba, o bien que exhiben el inicio de oleadas migratorias que, como la de los chinos a finales del siglo XIX, responden a demandas de mano de obra para satisfacer la expansión de actividades productivas y de transporte en determinadas zonas del país. ${ }^{29}$

Junto con estas continuidades, en las primeras décadas de la posrevolución los procesos de naturalización acusan la emergencia de nuevas nacionalidades. La participación de inmigrantes de Europa del Este ${ }^{30}$ en el total de naturalizados pasó de menos de $1 \%$ en el siglo xIx a $13 \%$ en la primera mitad del xx, mientras que los de Medio Oriente ${ }^{31}$ alcanzaron $8 \%$ de participación partiendo de una muy reducida presencia en el siglo XIX. De manera semejante se comportan los japoneses que, sin

29 Sin pretensión de exhaustividad, entre otros véase BERNINGER, La inmigración; MeYer, "Los franceses”; METz et al. Los pioneros; LIDA (comp.), Una inmigración; González Navarro, Los extranjeros; Meyer y SAlaZAR (coords.), Los inmigrantes; Bernecker, Alemania; Rodríguez Chávez (coord.), Extranjeros; Chao Romero, The Chinese; y SalaZAR, Las cuentas.

30 En la categoría Europa del Este se integraron las siguientes naciones: Albania, Bulgaria, Checoeslovaquia, Estonia, Hungría, Letonia, Lituania, Polonia, Rumania, Rusia, Ucrania y Yugoslavia.

31 En la categoría Medio Oriente se integraron las siguientes naciones: Arabia, Armenia, Egipto, Irán, Iraq, Líbano, Palestina, Siria y Turquía. 
representación en las naturalizaciones del siglo xIX, pasaron a $2 \%$ en la primera mitad de la pasada centuria.

\author{
Cuadro 1 \\ NATURALIZACIONES EN MÉXICO, 1828-1953
}

\begin{tabular}{lrr}
\hline Nación de origen & Totales & $\%$ \\
Alemania & 1613 & 5.16 \\
China & 1443 & 4.62 \\
Cuba & 486 & 1.56 \\
España & 12619 & 40.39 \\
Estados Unidos & 756 & 2.42 \\
Francia & 680 & 2.18 \\
Guatemala & 4907 & 15.70 \\
Grecia & 302 & 0.97 \\
Italia & 658 & 2.11 \\
Inglaterra & 256 & 0.82 \\
Japón & 431 & 1.38 \\
Líbano & 1117 & 3.57 \\
Lituania & 354 & 1.13 \\
Polonia & 1411 & 4.52 \\
Rusia & 954 & 3.05 \\
Siria & 559 & 1.79 \\
Turquía & 330 & 1.06 \\
Otras & 2369 & 7.58 \\
Total & 31245 & 100.00 \\
\hline
\end{tabular}

Fuente: AHDSRE, exps. L-E 1992; 26-23-97 y L-E 1993. 
De los poco más de 2500 extranjeros que se naturalizaron en el siglo XIx, casi la mitad fueron españoles, $10 \%$ estadounidenses, $8 \%$ franceses y alemanes respectivamente, $7 \%$ italianos, $5 \%$ guatemaltecos, $3 \%$ cubanos e ingleses respectivamente y $2 \%$ chinos. Si confrontamos esos porcentajes con lo sucedido con las 34000 cartas de naturalización entregadas en la primera mitad del siglo xx, se advierte en primer término que los chinos (5\%) y los guatemaltecos $(17 \%)$ aumentaron de manera significativa su representación; en segundo lugar que los españoles, si bien mantuvieron la primacía con una presentación de $40 \%$ en el total de naturalizados, en términos relativos y frente al siglo XIX su porcentaje disminuyó. En realidad, la disminución de españoles fue parte de un fenómeno general de adelgazamiento de las corrientes migratorias tradicionales, puesto que la participación de Europa occidental en el volumen total de naturalizados durante la primera mitad del siglo pasado pasó de $75 \%$ en el siglo xix a $50 \%$. Esta baja también se observa en los estadounidenses, que transitaron de $10 \%$ en el siglo xix a menos de $2 \%$ en la pasada centuria. Estas reducciones fueron capitalizadas por extranjeros provenientes de la zona del desintegrado imperio turco, por europeos del Este, por inmigrantes de China y Japón y por latinoamericanos, en su mayoría guatemaltecos.

Entre un siglo y otro los españoles acusaron la menor caída (47 a 39\%), los alemanes disminuyeron casi $40 \%$ al pasar de 8 a $5 \%$, mientras que las reducciones fueron drásticas para franceses ( 8 a $2 \%$ ), ingleses ( 3 a $0.62 \%$ ) italianos (7 a $2 \%$ ) estadounidenses (10 a $2 \%$ ) y cubanos (3 a 1 por ciento). 


\section{Gráfica 5}

NATURALIZADOS POR PAÍS DE ORIGEN 1828-1953

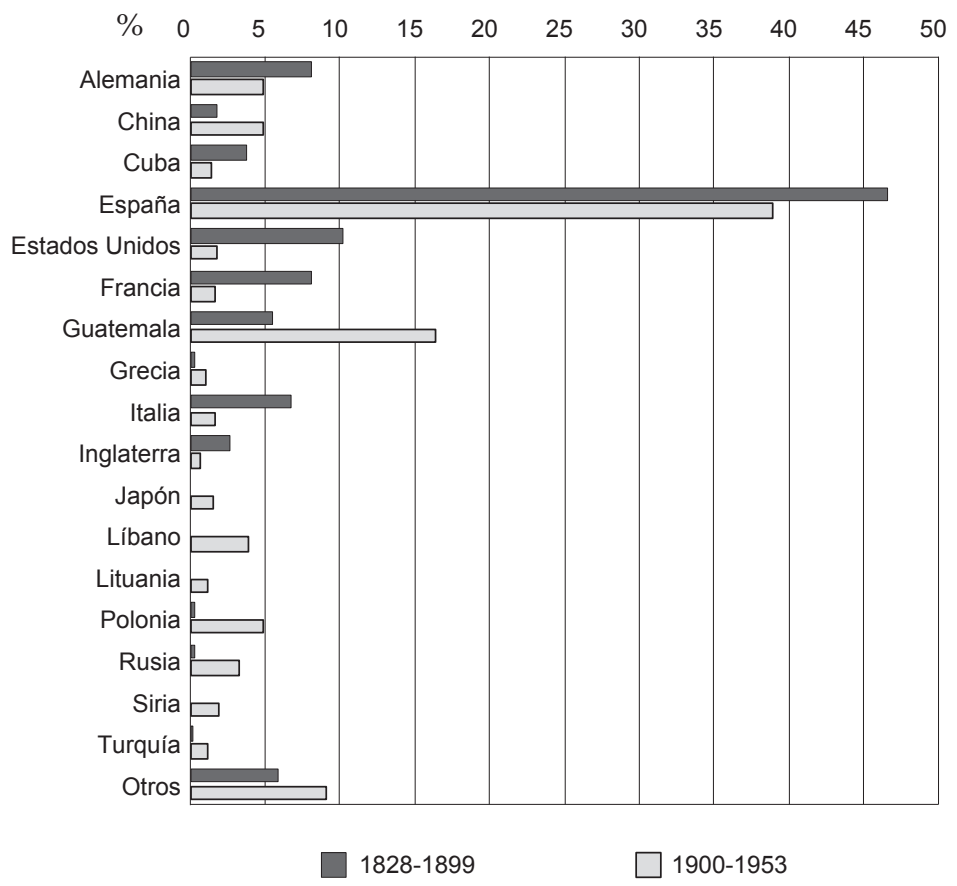

¿Cuáles podrían ser las causas de estas reducciones en naturalizaciones de extranjeros con arraigada presencia en México? En primer lugar, habría que considerar que durante la segunda mitad del siglo xIx franceses, italianos y en menor medida alemanes estuvieron asociados a experimentos de colonización agrícola que aunque débiles no encontraron continuidad en la siguiente centuria. ${ }^{32}$ En segundo término,

32 Véase Skerritt Gardner, Colonos; Viqueira y Ruz (eds.), Chiapas; Martínez Rodríguez, Colonizzazione, y Aboites, Norte. 
la migración francesa asociada a la peculiar experiencia de los barcelonnettes, ${ }^{33}$ iniciada alrededor de 1830 y que medio siglo más tarde estuvo plenamente consolidada, debió impactar en la participación francesa en el universo de naturalizados durante el siglo XIX; en tercer lugar, la independencia cubana cerró un ciclo de marcada presencia de estos antillanos en México en el siglo xix. ${ }^{34}$ Por último, la mengua de las naturalizaciones de estadounidenses, así como la de ingleses y alemanes entre la etapa anterior y posterior a la revolución de 1910, podría relacionarse con una legislación revolucionaria que al limitar derechos de propiedad aumentó los riesgos de renunciar a la protección de sus gobiernos para someterse al arbitrio de una autoridad mexicana. ${ }^{35}$ Es decir, se podría inferir que las restricciones que impuso la Revolución a inversiones contribuyeron poco a que estadounidenses y comunidades europeas con tradicional representación en México se inclinaran por la naturalización. Este asunto merece ser observado a la luz de quienes optaron por naturalizarse.

Para la primera mitad del siglo xx, y exceptuando los casos de los españoles y los guatemaltecos, que más adelante se examinarán, se puede trazar una evidente correspondencia entre las nacionalidades restringidas o prohibidas en la política migratoria y el incremento de su participación en las naturalizaciones.

$\mathrm{Al}$ concluir la primera guerra mundial se reactivaron los flujos migratorios internacionales hacia América. México

33 Véase Gouy, Pérégrinations; Proal y Charpenel, L’Empire; AntiQ-Auvaro, L'Émigration; y Gamboa (coord.), Los barcelonnettes. ${ }^{34}$ Véase Herrera Barreda, Inmigrantes.

35 Véase Knight, "Nationalism"; Freeman Smith, The United States; y Yankelevich, "Gringos". 
Gráfica 6

NATURALIZADOS POR ÁREA GEOGRÁFICA DE ORIGEN,

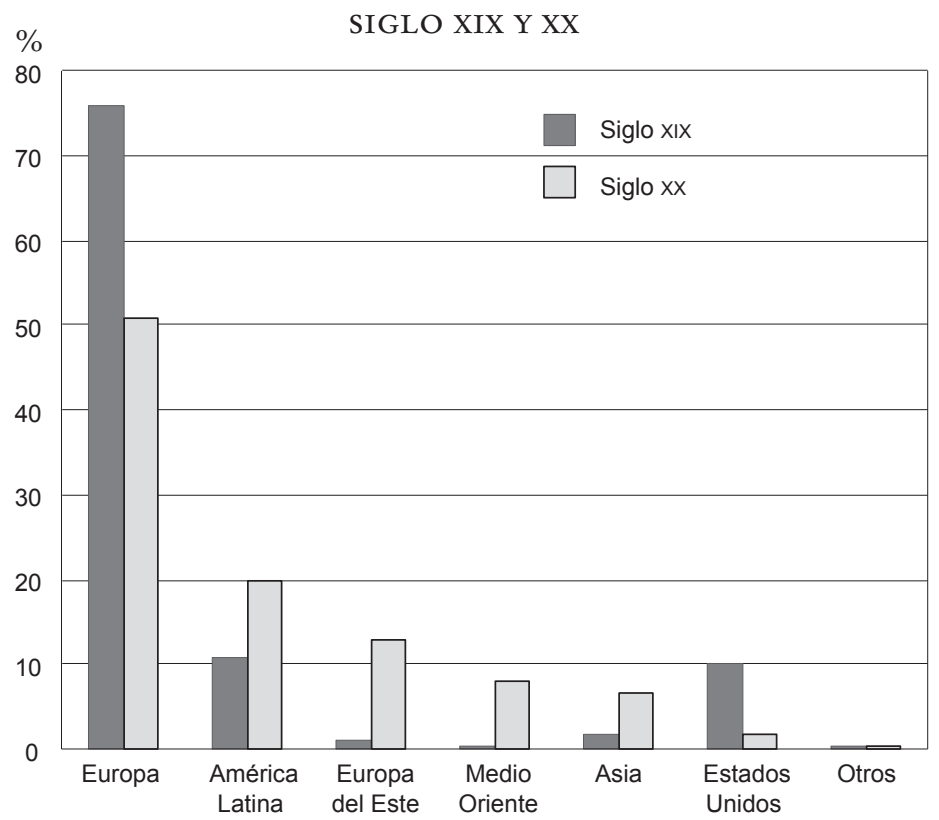

no fue la excepción aunque la vecindad con Estados Unidos imprimió características distintivas a este proceso. Explicar esas características obliga a tener en cuenta tres cuestiones. En primer lugar, los bajos índices de inmigración en México, que en buena medida se explican porque el país no podía competir con la enorme atracción que ejercía el mercado de trabajo estadounidense. En tal sentido, el crecimiento de la presencia de inmigrantes en México es producto de las políticas de restricción migratoria en Estados Unidos. Esto resulta claro en el caso de la comunidad china y japonesa, cuya expansión en México está directamente vinculada a las 
medidas prohibicionistas establecidas por las autoridades estadounidenses desde finales del siglo XIX, situación que se potenció cuando en 1924 quedó instituido un sistema de cuotas por nacionalidad que obligó a inmigrantes de Europa del Este y Medio Oriente a buscar alternativas en otras regiones de América. México entonces apareció como una oportunidad que podía ser temporal hasta conseguir cruzar la frontera de manera ilegal o bien para establecerse de manera definitiva en el país. En segundo lugar, la atracción que ejercía Estados Unidos alcanzó a los propios mexicanos, por ello y desde comienzos del siglo xx México comenzó a perfilarse como una nación de emigrantes. Los mexicanos que partían a Estados Unidos siempre superaron a los extranjeros que llegaban a radicar al país, y esta peculiar condición tuvo consecuencias determinantes en la política de migración, entre otras cuestiones por el impacto que tuvo en México la llegada de nacionales deportados cuando las crisis económicas golpearon la economía estadounidense en distintos momentos de la década de 1920 y hasta entrados los años treinta. ${ }^{36}$ En tercer lugar, las consecuencias de las políticas migratorias restrictivas en Estados Unidos y los problemas derivados del retorno compulsivo de emigrantes mexicanos se instalaron en un país impregnado por una potente prédica nacionalista que rápidamente se instaló en la política migratoria. La defensa de reducidos mercados labores fue uno de los pilares que sostuvo esa política, pero otro no menos vigoroso fue la defensa de una mexicanidad mestiza amenazada por inmigrantes con

36 Véase Balderrama E. y Rodríguez, Decade; Alanís Enciso, Que se queden; Henderson, Beyond, y Overmyer Velazquez (ed.), Beyond la Frontera. 
cargas culturales y biológicas supuestamente poco aptas para asimilarse a lo que se creía era el tipo nacional. No es casual entonces que desde inicios de la década de 1920 comenzara un ascendente proceso de restricción a la migración internacional, primero por medio de circulares confidenciales limitando el ingreso de asiáticos, negros, árabes, turcos, rusos, polacos, libaneses, etc., que engrosaban las nuevas corrientes migratorias. En un principio se prohibió a estos inmigrantes desarrollar actividades en las que competían con los nacionales, como fue el caso del trabajo como jornaleros y las actividades comerciales al menudeo; después se impidió el ingreso de nacionalidades "inasimilables", eufemismo con el que se hacía alusión a europeos del Este, en su mayoría de ascendencia judía, y a migrantes de la zona de Levante. Las campañas nacionalistas contra la presencia extranjera se iniciaron a comienzos de los años veinte y tuvieron como principal destinatario a los migrantes chinos. Esas campañas atravesaron toda esa década hasta alcanzar su punto culminante en 1931 y 1932, con la expulsión masiva de chinos en los estados norteños. Los antichinos no tardaron en incorporar otras fobias étnicas que decantaron en las nuevas campañas desplegadas en los años treinta contra extranjeros dedicados sobre todo al comercio y a dueños de pequeñas industrias. ${ }^{37}$

Durante la primera mitad del siglo xx se triplicó la población extranjera en México. Este incremento alcanzó en 1950 poco más de 180000 extranjeros en un universo de casi 26000000 de nacionales. A pesar de esta menguada representación en el volumen total de nacionales, la presencia de

\footnotetext{
37 Véase Pérez Montfort, Por la patria; Reñique, “Región”; Gojman DE BACKal, Camisas.
} 
extranjeros no dejó de valorase como una amenaza y en atención a ella entre 1920 y 1947 fueron sancionadas dos leyes de migración (1926 y 1930) y dos leyes generales de población (1936 y 1947), ${ }^{38}$ además de la nueva ley de naturalización (1934) referida en páginas anteriores. En buena medida estas normas fueron respuesta a un aumento de la demanda de extranjeros por conseguir visados que permitieran una residencia legal, y también de un aumento en la demanda de naturalizaciones por parte de extranjeros que tenían una prolongada residencia. Es posible suponer que ante leyes migratorias prohibicionistas y en un ambiente de marcada xenofobia, un número creciente de inmigrantes intentaran naturalizarse para conservar derechos de residencia, facilitar el ingreso al país de familiares y para garantizar empleos en negocios cuyas plantas laborales comenzaron a estar sujetas a un cupo de trabajadores extranjeros. ${ }^{39}$ Las naturalizaciones poco tuvieron que ver con una política oficial de integración y ciudadanización, y mucho menos con un interés de este tipo en los solicitantes, sino con una estrategia de estos últimos por alcanzar prerrogativas, sobre todo laborales, que eran recortadas por la legislación migratoria y del trabajo. En otros términos, en el México de la posrevolución una parte nada desdeñable de los extranjeros buscaron la naturalizaron para escapar de las restricciones migratorias en medio de un clima de exacerbado nacionalismo que amenazaba con expulsarlos.

\footnotetext{
38 Véase Yankelevich, ¿Deseables o inconvenientes?

39 Como resultado de las campañas nacionalistas, la Ley Federal del Trabajo aprobada en 1931 estableció en su artículo 9 que no se autorizaba más que $10 \%$ de extranjeros en la planta laboral de una empresa de cualquier ramo. Diario Oficial de la Federación (28 ago. 1931), p. 4.
} 
Para la primera mitad del siglo $\mathrm{xx}$, los extranjeros originarios de Europa del Este y Medio Oriente representan casi un tercio del total de naturalizaciones. Si se observa el comportamiento anualizado de esas naturalizaciones se advierte que el final de la primera guerra mundial marca el inicio de un ciclo que con altibajos se prolongó hasta la segunda posguerra. Un moderado ascenso caracteriza los años veinte para a partir de la crisis de 1929 comenzar un ascenso que alcanzará las cotas más elevadas en la primera mitad de los treinta, justamente en medio de la atmósfera más antiextranjera que respiró México durante el siglo pasado. Las naturalizaciones inician una fase de declive entre 1933-1934 en la coyuntura de la discusión y aprobación de la nueva ley de naturalización. En los años de 19361937 prácticamente se detiene el otorgamiento de cartas de naturalización para repuntar en los primeros años de la segunda guerra mundial acompañando una ligera apertura en materia migratoria consecuencia en buena medida de las nuevas obligaciones que el país había asumido con el ingreso a la guerra europea. De esta manera los momentos con mayores índices de naturalización fueron, por un lado, los primeros años treinta, atendiendo solicitudes que en su mayoría fueron hechas por inmigrantes que ingresaron al país una década antes; y por otro lado, durante los años de la segunda posguerra, cuando parte de los solicitantes corresponden a ingresos de finales de los años treinta y principios de los cuarenta.

Al comparar el flujo de naturalizaciones de extranjeros provenientes de Europa del Este y de Medio Oriente se advierten trayectorias similares con independencia de las diferencias en los volúmenes: 3672 europeos del Este y 2295 de Medio Oriente. Estos dos colectivos fueron objeto de normas y prohibiciones específicas. Desde finales de los años veinte y 


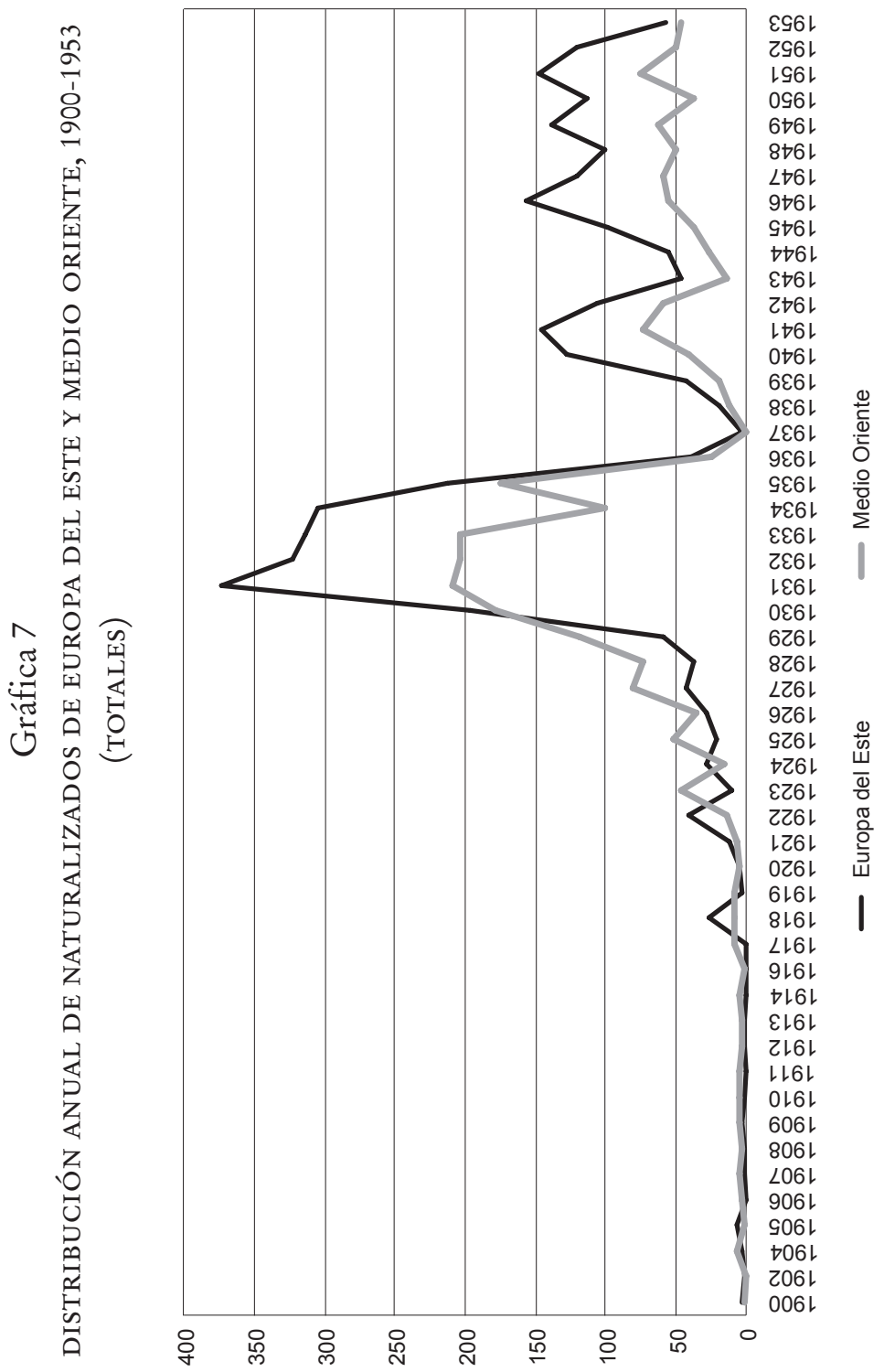


durante toda la siguiente década judíos, rusos, polacos, ucranianos, junto con árabes y judíos de Palestina, Líbano, Siria e Iraq fueron catalogados de extranjeros indeseables, dedicados a actividades "parasitarias" como el comercio ambulante y portadores de una innata incapacidad para integrarse a la cultura nacional. Estos extranjeros, huérfanos de protección de sus gobiernos e imposibilitados de emprender el viaje de regreso a sus naciones, entre otras cosas porque sus salidas muchas veces fueron huidas ante persecuciones étnicas, buscaron la nacionalidad mexicana a manera de refugio que permitiera librar las presiones, restricciones y obstáculos que imponía la autoridad mexicana.

Una situación similar se distingue en el caso de los chinos. Esta comunidad desde finales del siglo XIX comenzó a valorase como un peligro para la salud de la nación. El antichinismo, de fuerte raigambre popular en estados norteños, no encontró canales para una abierta manifestación pública durante los últimos años del porfiriato, entre otras cuestiones porque la llegada de los estos inmigrantes fue promovida desde el seno de la dirigencia nacional. Entre 1895 y 1910, la comunidad china creció de poco más de un millar a 13000, ${ }^{40}$ y este incremento no tardó en traducirse en un rechazo de tal magnitud que terminó, entre otros asuntos, dando origen a las primeras agencias gubernamentales dedicadas a controlar la inmigración en México. A medida que aumentaba el rechazo, los chinos buscaron la nacionalidad mexicana. Sobre el total de chinos naturalizados desde finales del siglo xIx hasta $1953,25 \%$ lo hizo entre 1889 y 1917 , mientras que en los siguientes 12 años (1918-1930) se naturalizaron 66\%.

${ }^{40}$ Censos, 1895-1910. 
El estallido de la Revolución abrió las puertas a un repudio que encontró explosiones de ira popular como fue el caso de la matanza de chinos en Torreón en $1911 .^{41}$ Estas fobias lograron articular una poderosa campaña en los estados norteños en donde se llegó al establecimiento de sistemas de exclusión étnica interesados en regular desde los lugares de residencia hasta los matrimonios. En este clima se alcanzaron los niveles más elevados de naturalizaciones, hasta que su descenso y prácticamente desaparición tuvo lugar a comienzos de los años treinta cuando sucedieron las expulsiones de orientales. Las fobias antichinas tuvieron continuidad en las fobias antijudías y antiárabes que vemos incrementar a medida que disminuyó la presencia de chinos en el país.

El caso de los guatemaltecos se distancia del resto de las comunidades de naturalizados. Ya se indicó que los guatemaltecos ocuparon el segundo lugar en el volumen de naturalizados entre 1828 y 1953. Se trata de casi 5000 personas, de las cuales menos de 300 obtuvieron su carta de naturalización en el siglo xix. El resto lo hizo en la primera mitad del siglo xx y cerca de $90 \%$ fueron naturalizaciones otorgadas entre 1936 y 1947. La alta concentración en un periodo tan corto obedece a condiciones peculiares en la definición y las actividades económicas de la frontera sur del país. En 1882 México y Guatemala llegaron a un acuerdo en una larga disputa por el trazado de la frontera. ${ }^{42}$ Como parte de esos acuerdos la zona del Soconusco quedó incorporada a México, y desde entonces este territorio vivió un expansivo crecimiento de la

\footnotetext{
${ }^{41}$ Véase Puig, Entre el río.

42 Véase Castillo, Toussaint y Vázquez, Espacios; y De Vos, Las fronteras.
} 


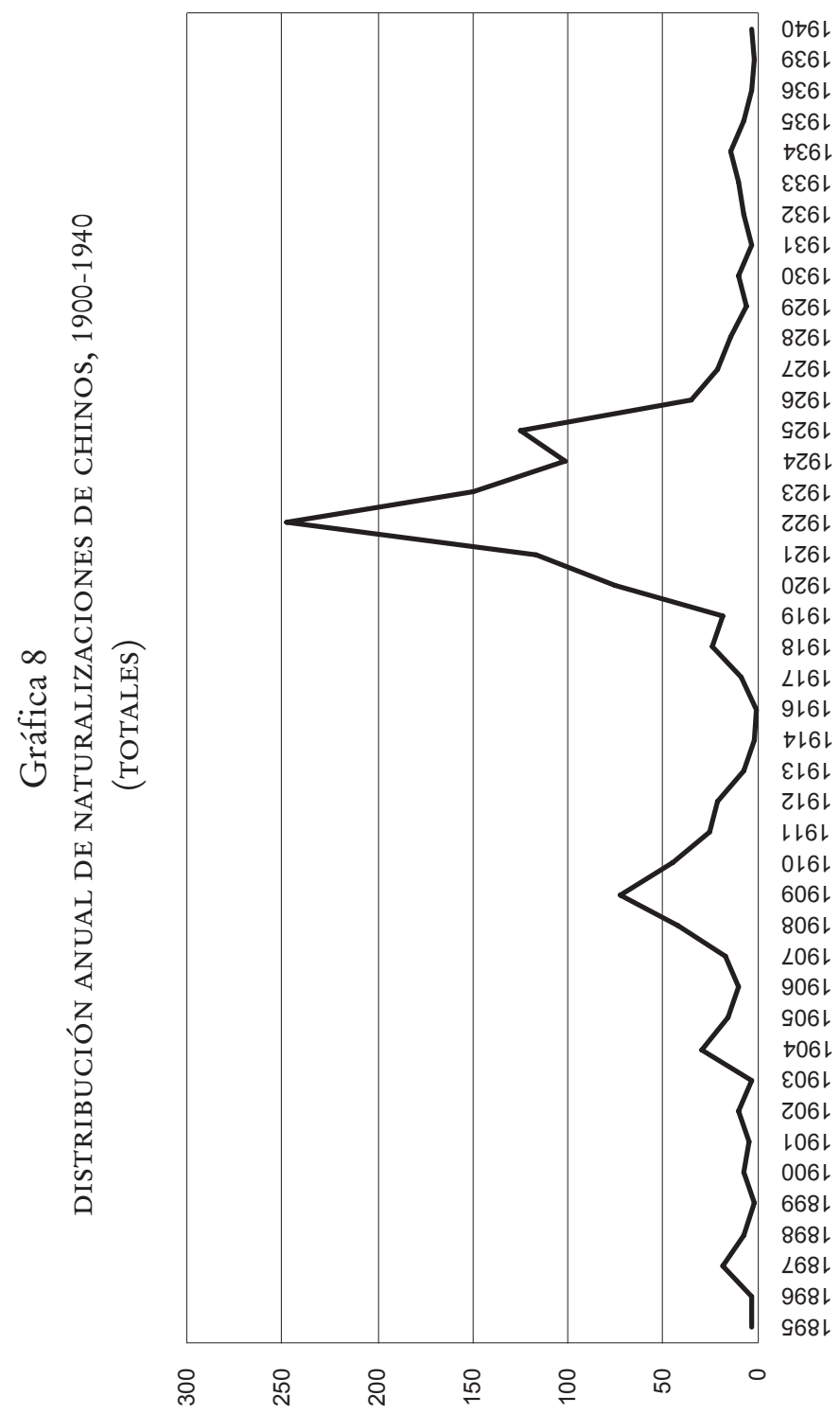


producción cafetalera fundada en haciendas de grandes proporciones y en el empleo intensivo de trabajadores residentes y de jornaleros temporales. Garantizar un regular abastecimiento de mano de obra fue un problema crónico de la económica cafetalera; por esta razón a la escasa población local se sumaron contingentes de trabajadores originarios del vecino país. Al origen rural de estos migrantes debe agregarse la condición de indígenas pertenecientes en su mayoría a la cultura mame. De esta forma, en la frontera sur se está en presencia de un colectivo de extranjeros con características diferentes a cualquier otra experiencia migratoria en México. ${ }^{43}$

En contraste con las pocas nacionalizaciones que se verificaron a finales del siglo XIX, que como demuestra Erika Pani respondieron en su mayoría a una estrategia de finqueros cafetaleros de retener mano de obra garantizando la propiedad de alguna parcela de tierra a sus trabajadores; ${ }^{44}$ las naturalizaciones que se sucedieron desde medianos de los años treinta fueron resultado de una política interesada en transformar esa zona fronteriza. El proceso de naturalización aparece asociado a una decisión gubernamental que se inició en los primeros años treinta y que se afianzó durante el gobierno de Lázaro Cárdenas.

Explicar el sentido de lo que en realidad fue una campaña masiva de naturalización obliga a tener en cuenta cuatro asuntos: en primer término, la indefinición de la nacionalidad en comunidades rurales que en su origen decimonónico habían sido guatemaltecas. En segundo lugar, las restricciones

43 Véase Castillo y Vázquez Olivera, “Los inmigrantes”; y MartineZ Velasco, Plantaciones.

${ }^{44}$ Véase Pani, Para pertenecer. 
migratorias que México impuso desde 1929 a raíz de la crisis económica mundial y que apuntaron contra jornaleros extranjeros que competían con los nacionales en muy estrechos espacios laborales. Estas restricciones no detuvieron la migración guatemalteca pero hicieron evidentes los mecanismos de reclutamiento ilegal usados por los finqueros, así como una sólida red de corrupción que los involucraba junto con autoridades locales y funcionarios del Departamento de Migración de la Secretaría de Gobernación. En tercer término, el ascenso de los reclamos campesinos durante los años veinte en las peculiares condiciones de Chiapas, entidad que había quedado al margen del proceso revolucionario debido a poderosos compromisos entre caciques políticos y hacendados. ${ }^{45} \mathrm{Y}$ por último, la puesta en marcha de las políticas indigenistas por medio de acciones específicas orientadas a combatir la marginación social propugnando por una integración de las comunidades indígenas a la nación mestiza.

Sobre estos antecedentes y bajo la presidencia de Lázaro Cárdenas tuvo lugar una amplia reforma agraria en el campo chiapaneco, ${ }^{46} \mathrm{y}$ como parte de esta política quedó constituida la Comisión Demográfica Intersecretarial (CDI), organismo integrado por la SRE, la Secretaría de Gobernación y el Departamento Agrario con la función de estudiar, proponer y ejecutar acciones tendientes a resolver la ausencia de nacionalidad en la mayoría de los pobladores de la región fronteriza formada por los departamentos de Soconusco y Mariscal. Los guatemaltecos y sus hijos carecían de documentación que acreditara su nacionalidad, y en iguales circunstancias esta-

\footnotetext{
${ }^{45}$ Benjamin, A Rich Land.

${ }^{46}$ Reyes Ramos, El reparto.
} 
ba la mayoría de los mexicanos que trabajaban en las fincas cafetaleras. Por esta razón los abusos, maltratos y todo tipo de arbitrariedades dirigidos a guatemaltecos alcanzaron también a mexicanos. Resolver este asunto no era una cuestión menor, toda vez que de la nacionalidad dependía de que los trabajadores permanentes y los jornaleros fueran sujetos de derecho agrario. ${ }^{47}$

Desde 1932 el gobierno federal mostró interés por conocer y ordenar el estado de la migración en aquella región del sur mexicano. Mediante reuniones binacionales los gobiernos de México y Guatemala pusieron en evidencia la absoluta falta de control sobre los flujos migratorios, y en consecuencia el Departamento Migratorio de México inició un esfuerzo por elaborar censos y registrar a la población guatemalteca. ${ }^{48}$ Estos fueron los primeros pasos de un trabajo que fue retomado por la CDI. Esta comisión comenzó a trabajar en 1935 y clausuró una primera etapa en 1940. Un año más tarde fue reorganizada y funcionó hasta $1947 .^{49} \mathrm{Si}$ se examina la distribución anual de naturalizados guatemaltecos se advierte

${ }^{47}$ El Código Agrario de 1934 establecía en su artículo 44 que para recibir una dotación ejidal era necesario acreditar la condición de mexicano, sin distinguir entre mexicanos por nacimiento o por naturalización. Diario Oficial de la Federación (12 abr. 1934), p. 601. La condición de mexicano por nacimiento quedó estipulada en el nuevo Código Agrario de 1940 en su artículo 163. Diario Oficial de la Federación (29 oct. 1949), p. 57.

${ }^{48}$ La documentación de estas reuniones binacionales en que se examinó el problema migratorio en la frontera sur puede consultarse en AHINM, 4-358-447 y AHDSRE, III-1728-1 (4 partes), III-170-19.1938, III296.31.1934, CILA 334.4 y CILA X 334.4.

49 Para una aproximación histórica al trabajo de la CDI, véanse Gerardo Pérez, "Nacionalidad", y Castillo y Vázquez Olivera, "Los inmigrantes". 
que entre esos años se concentra casi $90 \%$ de las naturalizaciones. En los hechos, la CDI funcionó como un registro civil ya que mediante declaraciones de los interesados, de testigos y de la poca documentación con que se contaba otorgó cartas de naturalización a aquellos que declaraban haber nacido en Guatemala, y certificados de nacionalidad a descendientes de guatemaltecos nacidos antes de la adopción del principio de ius soli en 1934. De igual manera, y según un informe de 1940, la CDi logró identificar a más de 40000 personas que pudieron demostrar la condición de mexicanos. ${ }^{50}$

La elevada tasa de naturalización de guatemaltecos derivó de la necesidad gubernamental de conocer y ordenar la población asentada en una frontera sobre la que se había ejercido un escaso control. Las naturalizaciones se atribuyeron en un contexto de acrecentada movilización política destrabada por un reclamo de tierras de las comunidades campesinas. Fue así que se naturalizó para dotar de tierras o para dar seguridad a beneficiarios de dotaciones ya realizadas que carecían de herramientas idóneas para acreditar su nacionalidad.

Si el caso guatemalteco fue resultado de una situación excepcional, algo similar aconteció con los españoles a pesar de constituir la principal comunidad de naturalizados desde la primera década de la posindependencia. En términos cuantitativos los españoles tuvieron la más alta participación en la historia de la inmigración en México hasta mediados del siglo xx. ${ }^{51}$ La tradición y consistencia de esta migración explica que de poco más de 31000 naturalizaciones entre 1828 y

\footnotetext{
50 Gerardo Pérez, “Nacionalidad”, p. 193.

51 Véase Pla Brugat, “Españoles”; Lida, Inmigración, cap. 2, y “Los españoles”; Gil Lázaro, "La presencia”.
} 


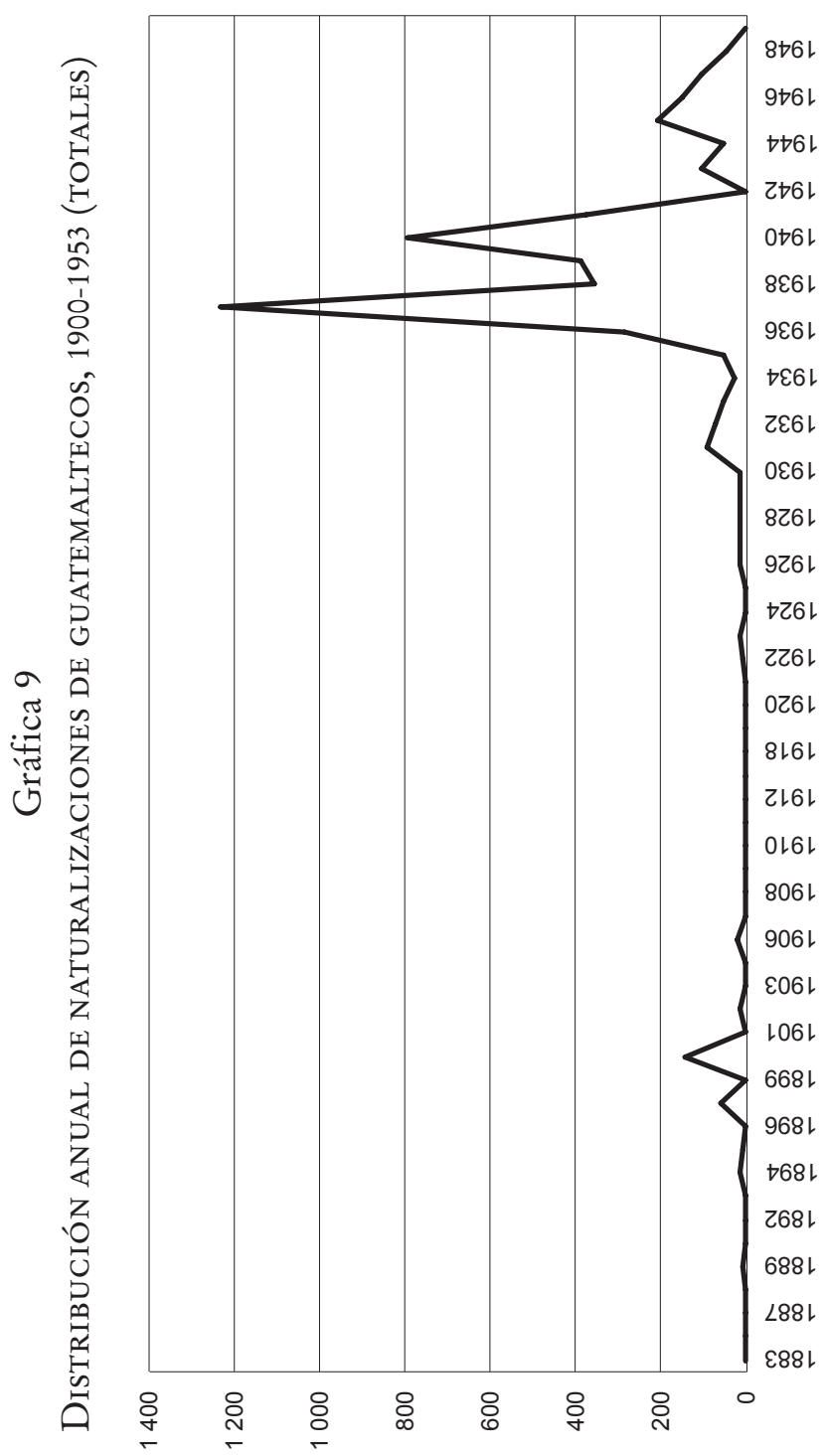


1953 hayan sido de españoles más de 12300. Sin embargo, al analizar estas cifras se advierte que de ese total de españoles naturalizados sólo 10\% tuvo lugar en el siglo xix. La búsqueda de la naturalización para los integrantes de la comunidad extranjera con mayor raigambre en México no parece haber sido una aspiración muy sentida, o si lo fue no parece haber sido fácil alcanzarla. El estudio de Érika Pani demuestra que en la primera razón radica la causa de índices tan bajos. Conservar la condición de súbdito de la corona española en medio de las turbulencias políticas, guerras y asonadas del México decimonónico otorgaba mayores seguridades a propiedades y vidas que el orgullo de pertenecer a la "gran familia mexicana". ${ }^{2}$ Esta actitud parece confirmarse de tener en cuenta que la mitad de los españoles naturalizados antes del estallido de la revolución de 1910 lo hizo en las décadas de la pax porfiriana, cuando la estabilidad política y las seguridades otorgadas a inversionistas y empresarios seguramente impulsaron la búsqueda de la nacionalidad.

Las naturalizaciones en la posrevolución siguieron otras rutas. Los españoles no escaparon a los rechazos que alentó el nacionalismo revolucionario. Por el contrario, ese nacionalismo se afianzó a partir de una memoria que insistía en vincular las renovadas oleadas de migrantes españoles con los conquistadores y colonizadores de los siglos virreinales. El paradigma de extranjero abusivo y explotador era el migrante español, de ahí las palabras del diputado constituyente Paulino Machorro, cuando en enero de 1917 en Querétaro aseveró que cada vez que veía a un extranjero "se me figura que por las baldosas de nuestras banquetas resuenan aún los aci-

52 PANI, Para pertenecer. 


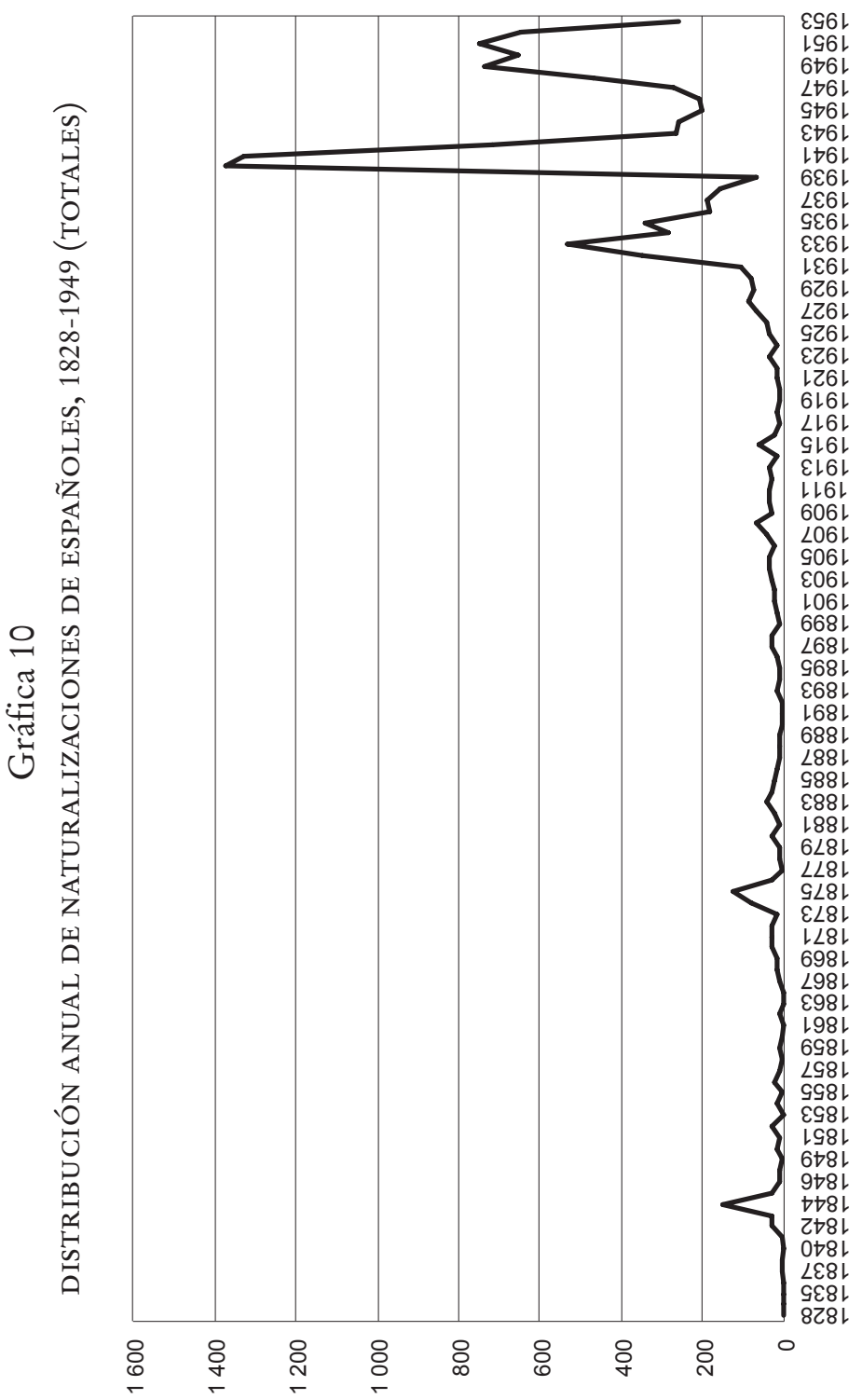


cates de Pedro de Alvarado". ${ }^{33}$ Un clima hispanófobo inundó la inmediata posrevolución, potenciado en buena medida por el recuerdo de favores y privilegios de que gozaron los sectores más encumbrados de la colonia española durante el porfiriato y por las apuestas políticas de estos mismos sectores a la contrarrevolución. ${ }^{54}$ Por otra parte, España en el nuevo siglo carecía de capacidad para promover con algún éxito la defensa de sus nacionales en el extranjero, de manera que la conservación de la nacionalidad española no otorgaba más que la honra de ser súbdito de la monarquía.

Ese clima antiespañol se enrareció aún más con la puesta en marcha de normas migratorias restriccionistas, por ello la búsqueda de la nacionalidad mexicana, al igual que en otras comunidades de extranjeros que resistieron las restricciones y prohibiciones, se perfiló como una estrategia defensiva para garantizar derechos de propiedad y residencia. La distribución anual de naturalizaciones evidencia un incremento sustancial de las naturalizaciones en el quinquenio 1931-1935 correspondientes a solicitudes efectuadas desde finales de los años veinte en medio de aquel clima de nacionalismo exacerbado, mientras que la caída en el trienio 1936-1939, de la misma manera que en el resto de las nacionalizaciones, puede atribuirse a los reajustes administrativos que impuso tanto la nueva ley de extranjería de 1934 como la de población de 1936.

Ahora bien, si entre 1828 y 1939 el promedio de naturalizaciones de españoles fue de 43 cartas al año, entre 1940 y 1953 el promedio alcanzó las 565 cartas anuales. En estos últimos

${ }^{53}$ Diario de Debates, $33^{\circ}$ Sesión Ordinaria, Intervención de Paulino Machorro Narváez (6 ene. 1917), p. 1443.

${ }^{54}$ Véase Illades, Presencia, y Yankelevich, "Hispanofobia”. 
14 años se naturalizaron $65 \%$ de todos los españoles a lo largo de 125 años. La razón de esta expansión está directamente asociada a una circunstancia excepcional en la política migratoria de México: la solidaridad con los refugiados de la Guerra Civil Española.

A inicios de 1940 el gobierno de México introdujo un cambio en la Ley de Nacionalidad y Naturalización de 1934 como parte de una serie de acciones para facilitar la recepción de este amplio contingente de perseguidos políticos. Entre los requisitos para acceder a la nacionalidad por una vía privilegiada, es decir, sin la mediación del poder judicial y sin la condición de acreditar cinco años de residencia, la Ley de 1934 había incluido a los originarios de países latinoamericanos. Este había sido un insistente reclamo de los constituyentes, al punto que como ya se ha indicado, la condición de "indoamericano" quedó incorporada al texto constitucional de 1917. En Querétaro, y sobre esta prerrogativa, de manera expresa se excluyó a los españoles, considerados en opinión de Francisco Múgica "perniciosos por excelencia”. ${ }^{55}$ Con el arribo de los republicanos esta percepción cambió sustancialmente, de modo que meses después de la llegada del primer contingente de refugiados, por decreto presidencial se incorporó en la Ley de 1934 el origen español como sujeto de privilegio para acceder a la nacionalidad mexicana. ${ }^{56}$

${ }_{55}$ Diario de Debates, $33^{\circ}$ Sesión Ordinaria, Intervención de Francisco Múgica (6 ene. 1917), p. 1447.

${ }^{56}$ En enero de 1940 se modificó la fracción VII del artículo 21 de la Ley de 1934, estableciendo que serían beneficiarios de la vía extraordinaria de naturalización "los indolatinos y los españoles de origen que establezcan su residencia en la República", Diario Oficial de la Federación (23 ene. 1940), p. 2. 
En las primeras páginas de este estudio se hizo referencia a las controversias que generó la necesidad de regular el acceso a la nacionalidad mexicana. A partir de 1917 las discusiones fueron ríspidas, sobre todo cuando se trató de fijar requisitos para asegurar que las solicitudes de naturalización obedecieran a la convicción profunda de desear integrarse a la nación mexicana. Resulta excepcional que ninguno de estos dilemas se interpuso a la voluntad del presidente Lázaro Cárdenas en su solidaridad con los derrotados de la Guerra Civil Española; y justamente por ello se inauguró una experiencia de naturalizaciones "masivas" que permitieron en primer lugar obtener un pasaporte a quienes por las circunstancias de su salida carecían de documentación que acreditara su identidad. En segundo lugar, facilitó inserciones laborales en mercados de trabajo que restringían la presencia extranjera, mercados en los que además y sobre todo en el sector gubernamental, el origen español era motivo de un particular recelo $;^{57} \mathrm{y}$ en tercer lugar, la dirigencia mexicana expresó su anhelo de que un inmediato acceso a la nacionalidad condujera a enraizar a estos españoles valorados por sus antecedentes étnicos y políticos como los extranjeros "deseables por excelencia."

Entre 1940 y 1944 se naturalizaron 2532 refugiados españoles. Es decir, en ese quinquenio se otorgó la nacionalidad a poco más de $20 \%$ de todos los españoles que se convirtieron en mexicanos durante algo más de un siglo. Ahora bien, la importancia de este asunto no radica sólo en lo excepcional de una presencia extranjera vinculada a una migración política, sino sobre todo a que la decisión del gobierno mexicano impactó de inmediato en los antiguos residentes españoles.

57 Véase Pérez Vejo, “España”, y Dávila Valdés, Refugiados, cap. 6. 
Las facilidades para una rápida naturalización de los refugiados fueron aprovechadas por integrantes de la tradicional colonia española al punto que sus volúmenes de naturalización se incrementaron desde 1940 al amparo de la prerrogativa otorgada para atender el caso de los republicanos, y tres años más tarde ese volumen ya había superado al del exilio republicano. A partir de 1944 se carece de herramientas que permitan desagregar uno de otro colectivo español en el total de naturalizaciones; sin embargo, es posible especular que para el caso de los republicanos las expectativas de un pronto retorno, a partir del triunfo de los ejércitos aliados en la segunda guerra mundial, debieron haber desalentado las naturalizaciones, para volver a incrementarse a partir de 1948 cuando, en el marco de la guerra fría, el gobierno estadounidense hizo manifiesto su apoyo al franquismo.

\section{LUGARES DE RESIDENCIA}

Dos terceras partes de los naturalizados en la primera mitad del siglo xx tuvieron residencia en siete estados de la República y en la ciudad capital. En los estados norteños de Baja California, Chihuahua, Coahuila y Sonora residieron $7 \%$ de los naturalizados, en Chiapas poco más de $15 \%$, y en Veracruz 3\%. Los patrones de dispersión geográfica corresponden a espacios tradicionales de asentamiento de las comunidades extranjeras, destacando para el siglo xx la excepcionalidad cosmopolita de la ciudad de México, que concentraron más de $50 \%$ de los naturalizados distribuidos entre 62 nacionalidades de origen. ${ }^{58}$

${ }^{58}$ Estas nacionalidades fueron: albanesa, alemana, árabe, argentina, armenia, australiana, austriaca, belga, boliviana, brasileña, búlgara, canadiense, 


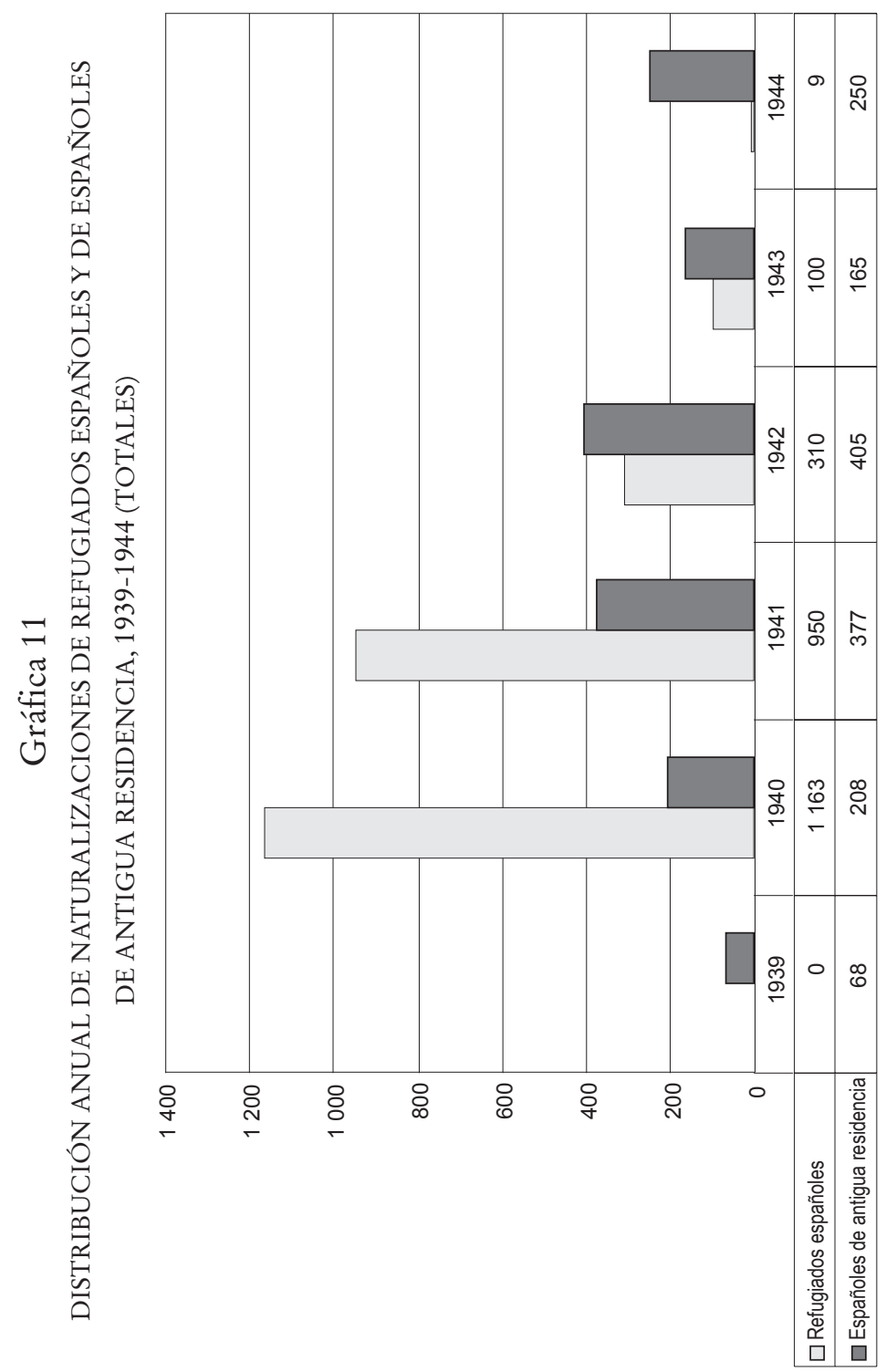




\section{Gráfica 12}

NATURALIZADOS POR LUGAR DE RESIDENCIA, SIGLOS XIX Y XX

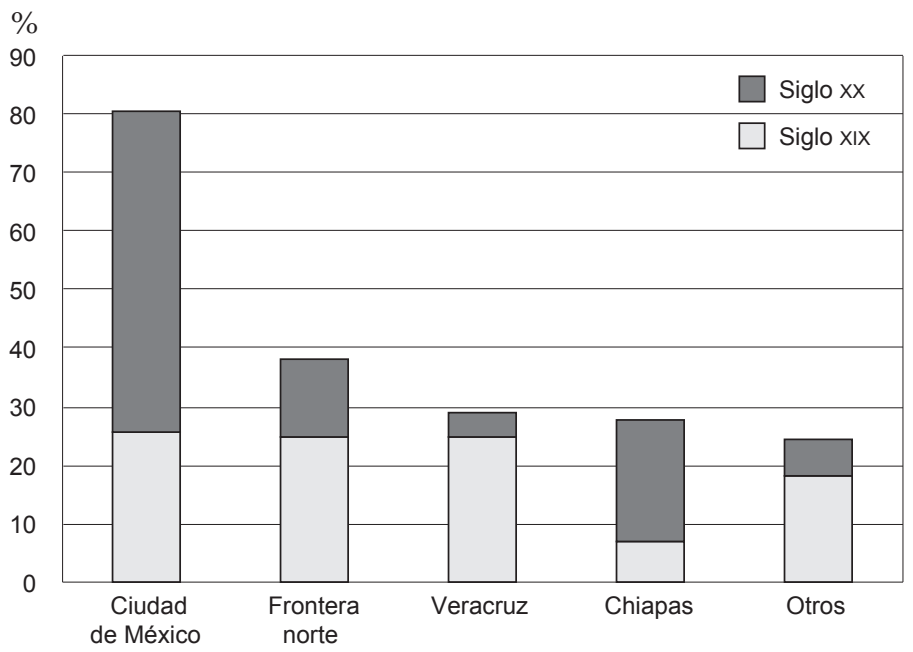

Si se cotejan estos datos con los del siglo xix hasta el estallido de la revolución de 1910, se advierte que en lo sustancial no se modificaron los principales sitios de residencia (frontera norte, Chiapas, Veracruz y ciudad de México) aunque sí cambiaron los volúmenes. La representación de la frontera norte y del estado de Veracruz descendió en forma significativa y en contraste los valores de las naturalizaciones en

checoslovaca, chilena, china, colombiana, coreana, costarricense, cubana, danesa, dominicana, ecuatoriana, egipcia, española, estadounidense, estonia, filipina, finlandesa, francesa, griega, guatemalteca, haitiana, holandesa, hondureña, húngara, india, inglesa, iraní, iraquí, italiana, japonesa, letona, libanesa, lituana, luxemburguesa, nicaragüense, noruega, palestina, panameña, peruana, polaca, portuguesa, rumana, rusa, salvadoreña, siria, sueca, suiza, turca, ucraniana, uruguaya, yugoslava y venezolana. 
la ciudad México pasaron de 25 a 55\%. Chiapas aumentó su participación, fenómeno directamente asociado a la ya referida política de naturalización de guatemaltecos. De este modo, la mayoría de los extranjeros que obtuvieron cartas de naturalización en la posrevolución residieron en la ciudad de México y en Chiapas. Explicar este fenómeno obliga a tomar en cuenta dos asuntos: en primer lugar, el expansivo crecimiento de la capital del país y la consecuente atracción que ejerció en materia laboral tanto para nuevas oleadas de inmigrantes extranjeros como para los antiguos que pudieron haber cambiado de residencia a consecuencia de la agitación revolucionaria en el interior del país. ${ }^{59}$ Entre 1910 y 1950, la población extranjera en la ciudad de México pasó de 25872 a 65187 personas; ${ }^{60}$ el crecimiento más significativo tuvo lugar en las décadas de 1930 y 1940, cuando esa población casi se duplicó. El flujo de cartas de naturalización a extranjeros dibuja esta trayectoria; las naturalizaciones comienzan a aumentar a mediados de los años veinte para alcanzar sus niveles máximos en las décadas siguientes (véase la gráfica 1). En segundo lugar, la cercanía a las oficinas de la SRE donde se tramitaban las naturalizaciones debió agilizar gestiones realizadas en cumplimiento de trámites en particular enmarañados. Esta circunstancia probablemente insidió en la concentración de naturalizaciones de residentes en la capital del país.

Sobre el total de naturalizados en esta ciudad entre 1910 y 1953 (11 864 personas) 63\% fueron españoles, 13\% fueron

${ }^{59}$ Véase Martínez Assad (ed.), La ciudad, y Rodríguez Kuri (coord.), Historia política.

${ }^{60}$ Censos, 1910, 1921, 1930, 1940 y 1950. 
originarios de Europa del Este, 5\% de Medio Oriente, y poco menos de $1 \%$ de Asia.

\section{Gráfica 13}

\section{NATURALIZADOS EN LA CIUDAD DE MÉXICO POR NACIÓN/}

REGIÓN DE ORIGEN, 1900-1953

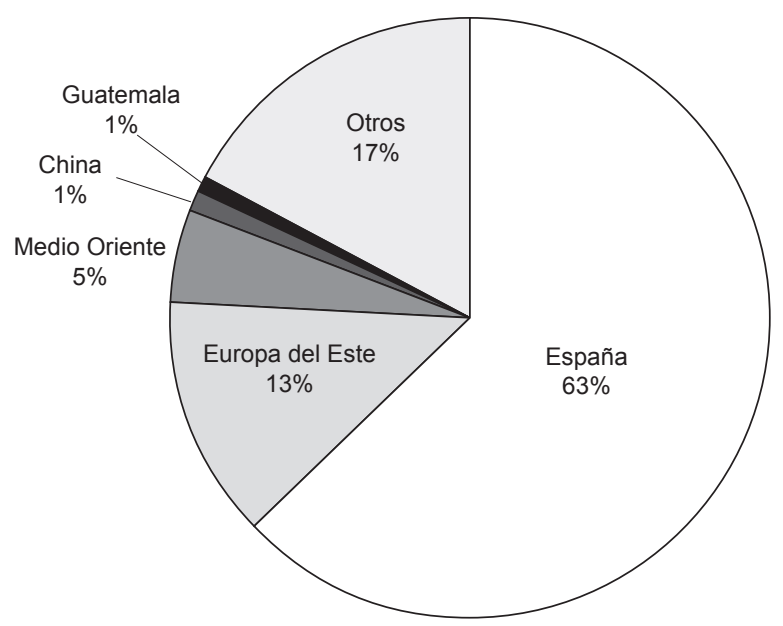

La dispersión por nacionalidad y sus respectivos volúmenes presentan variaciones importantes si se revisan las entidades que concentran las mayores magnitudes de naturalizaciones. Por ejemplo, en Chiapas estuvieron representadas 19 nacionalidades, pero los guatemaltecos representaron 97\% de los naturalizados. En Sonora los nacionalizados pertenecieron a 27 nacionalidades, casi $70 \%$ fueron chinos y el resto se distribuyó entre españoles 6\%, japoneses 5\%, nativos de Europa del Este 5\%, estadounidenses 4\%, alemanes 3\% y poco menos de 3\% oriundos de Medio Oriente. En Chihuahua estuvieron presentes 26 nacionalidades aunque con una 
participación menos concentrada que en los casos anteriores: chinos 34\%, españoles 24\%, Medio Oriente 11\%, Europeos del Este 7\%, japoneses $7 \%$, estadounidenses 6\% y alemanes 3\%. Por su parte, Baja California se comporta de manera similar a Chihuahua; $35 \%$ de chinos, $24 \%$ de españoles, $9 \%$ de japoneses, 5\% de Europa del Este y 3\% de Medio Oriente.

Más de las dos terceras partes de los naturalizados de origen chino y japonés residieron en los estados norteños, sólo en Sonora vivieron cerca de $40 \%$ de los chinos que obtuvieron su naturalización en la primera mitad del siglo xx. Los nativos de Medio Oriente y Europa del Este muestran patrones de residencia diferenciados. Los primeros alcanzan una representación en la ciudad de México de $50 \%$, que contrasta con $80 \%$ de los segundos. La mayoría de los libaneses, sirios, palestinos, turcos, etc., se distribuyeron entre la capital del país y los estados de Coahuila, Chihuahua, Nuevo León, Veracruz, Tamaulipas y Yucatán, mientras que la mayoría de rusos, ucranianos, polacos, etc., se asentaron en la capital del país.

El peso de la ciudad de México también es manifiesto en los naturalizados de origen español. De los españoles naturalizados, $80 \%$ residieron en la capital. Esta concentración crece hasta $95 \%$ en el caso de los republicanos españoles y desciende a $75 \%$ si se trata de antiguos residentes españoles. Es decir, a lo largo de los primeros 50 años del siglo pasado, de los casi 9500 españoles naturalizados, 7500 vivieron en la capital, y de ellos poco más de 2200 fueron republicanos españoles. La ciudad de México fue casi exclusivamente el lugar de residencia de los republicanos naturalizados, mientras que la antigua colonia tuvo alguna representación en los estados de Baja California, Chihuahua, Coahuila, Puebla, Tamaulipas, Veracruz y Yucatán. 
Gráfica 14

NATURALIZADOS DE CHINA POR LUGAR DE RESIDENCIA, 1900-1953

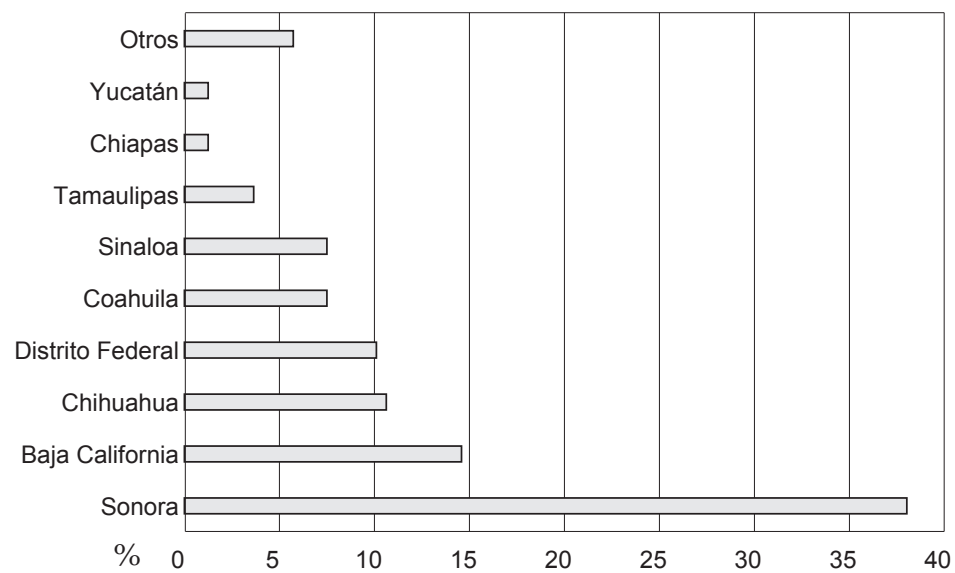

Gráfica 15

NATURALIZADOS DE MEDIO ORIENTE POR LUGAR

DE RESIDENCIA, 1900-1953

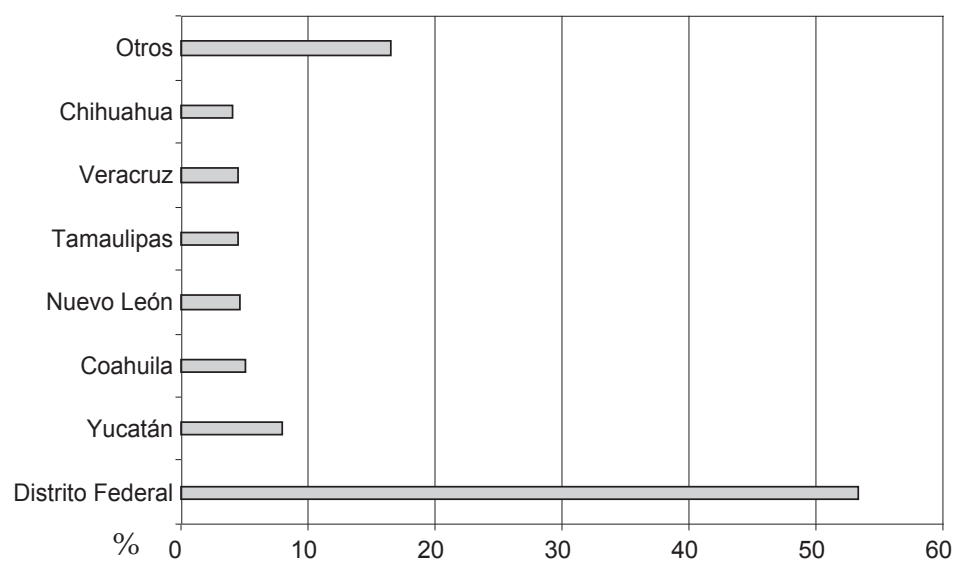


A excepción de los asiáticos y guatemaltecos, el resto de las nacionalidades se concentró mayoritariamente en la capital. En la frontera norte, las distribuciones por nacionalidad muestran grados diferentes de dispersión entre nativos de Europa occidental y oriental, Medio Oriente y Extremo Oriente; en cambio, en la frontera sur la vecindad con Guatemala concentró el origen nacional de los naturalizados. Los españoles, a pesar de constituir la comunidad con mayor dimensión de naturalizados, y con la mayor distribución geográfica, no escaparon a un patrón de asentamiento capitalino que domina en el universo de los mexicanos por naturalización, circunstancia que resulta corolario del volumen de las comunidades radicadas en la capital y también de las facilidades de realizar los trámites con un domicilio próximo a la administración del poder federal.

\section{ESTADO CIVIL Y SEXO}

La naturalización fue una cuestión de hombres. A lo largo de la primera mitad del siglo xx sólo 7\% de todos los naturalizados fueron mujeres. Se trató de poco más de 2100 mujeres, de las cuales $47 \%$ fueron españolas, $23 \%$ guatemaltecas, $6 \%$ de Europa del Este y 3\% de Medio Oriente.

En todas las nacionalidades la presencia masculina superó $90 \%$; el caso extremo fueron los chinos, con un índice de masculinidad de 100\%. Este índice sólo disminuye en la comunidad guatemalteca, al alcanzar una participación femenina de 12 por ciento.

El escaso peso femenino en las naturalizaciones ( $7 \%$ ) contrasta con las tasas censales promedio de $37 \%$ que registran 


\section{Gráfica 16}

MUJERES NATURALIZADAS POR NACIÓN/REGIÓN DE ORIGEN, 1900-1953

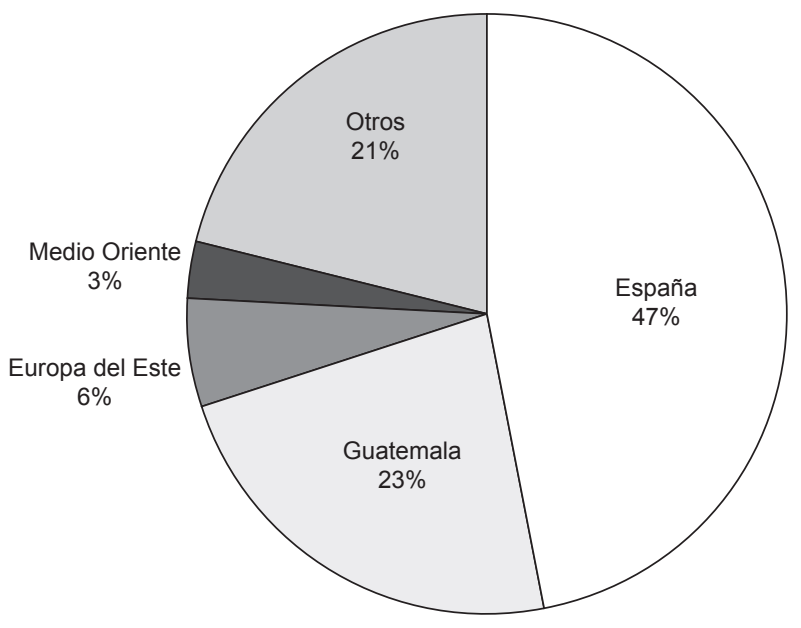

Gráfica 17

HOMBRES Y MUJERES NATURALIZADOS POR NACIÓN/REGIÓN DE ORIGEN, 1900-1953

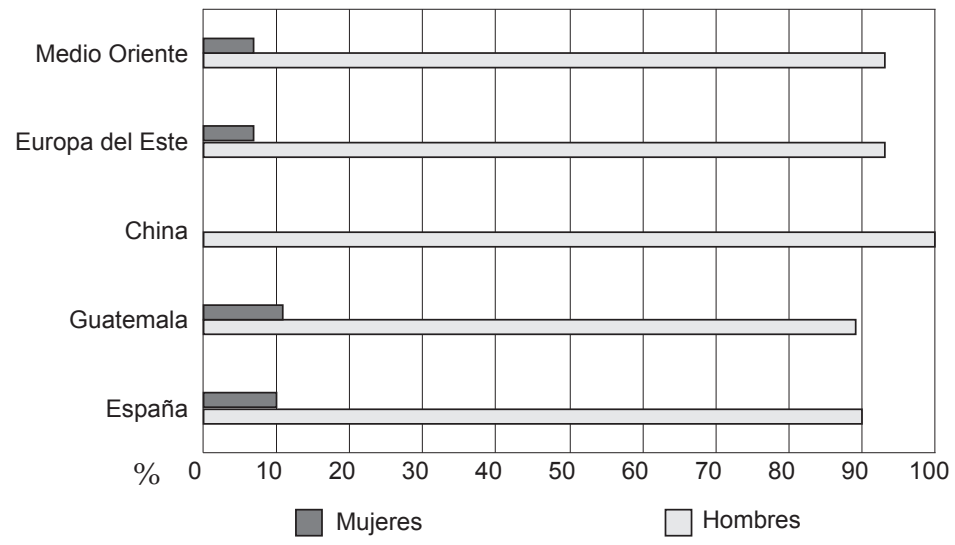


las mujeres extranjeras en México entre 1910 y $1950 .{ }^{61}$ ¿Cómo explicar esta situación? Si se interroga acerca de los incentivos que pudieron llevar a una mujer a naturalizarse quizá sea posible hallar algunas de las razones de la exigua participación femenina. En primer lugar, habría que descartar aspiraciones de ejercicio de derechos ciudadanos, toda vez que no hay evidencias de reclamos de este tipo, y por otro lado, la instauración del voto femenino y su posible impacto en la naturalización de mujeres fue posterior al límite cronológico de este estudio. En segunda instancia, habría que considerar el estado civil de esas mujeres, ya que antes de la Ley de Naturalización de 1934 una extranjera casada con mexicano adoptaba en forma automática la nacionalidad del esposo. Por ello no resulta extraño que más de las dos terceras partes de las cartas de naturalización a mujeres a lo largo de la primera mitad del siglo xx hayan sido emitidas después de 1934. Una proporción cercana a $30 \%$, es decir, casi 600 mujeres, estaban casadas; se podría suponer que este universo estuvo integrado por esposas que hicieron sus trámites de naturalización junto a sus maridos extranjeros, y también por extranjeras casadas con mexicanos al amparo de la vía de privilegio que estipuló la ley de 1934. En ambos casos, la nacionalidad por opción pudo buscarse para obtener seguridad jurídica sobre propiedades o para el ejercicio de actividades laborales. Por último, fueron solteras 980 mujeres, $52 \%$ del total de naturalizadas. Contrariamente a lo que podría suponerse, para las mujeres el casamiento no fue una condición socorrida para obtener la nacionalidad, al contrario de lo que acontece con los hombres, quienes duplican el índice de matrimonio. Es posible

${ }^{61}$ Censos, 1910, 1921, 1930, 1940 y 1950. 
que el principio de igualdad jurídica entre cónyuges instituido en la Ley de 1934 impulsara a mujeres solteras, viudas y divorciadas a pedir la nacionalidad mexicana, tratando de resguardar patrimonios familiares que podían verse amenazados ante la doble vulnerabilidad de ser mujer y extranjera.

Gráfica 18

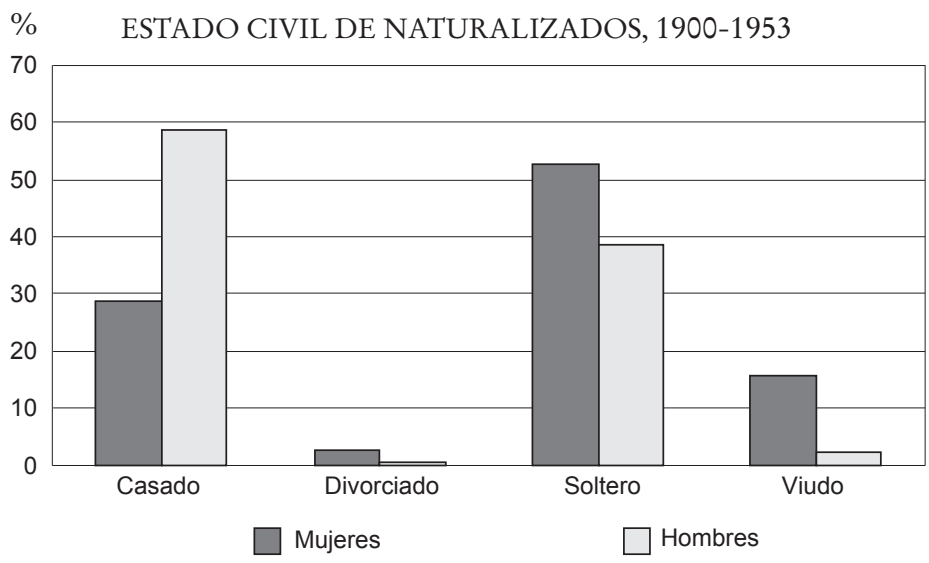

Por otra parte, una mirada al estado civil de los naturalizados sin una desagregación por sexo arroja luz sobre el comportamiento diferenciado de las principales colectividades. En la primera mitad del siglo xx, 55\% estuvo casado y $40 \%$ soltero. Sin embargo, al discriminar por nacionalidades o por regiones de origen se advierte que los índices de soltería disminuyen a cifras entre 6 y $8 \%$ en las comunidades con mayor incidencia de las restricciones migratorias (asiáticos, europeos del Este y nativos de Medio Oriente). En estas colectividades el casamiento alcanza a $90 \%$ de los naturalizados, mientras que en los españoles se ubica en $61 \%$ y en los guatemaltecos en 14 por ciento. 


\section{Gráfica 19}

ESTADO CIVIL DE NATURALIZADOS POR NACIÓN/REGIÓN DE ORIGEN, 1900-1953

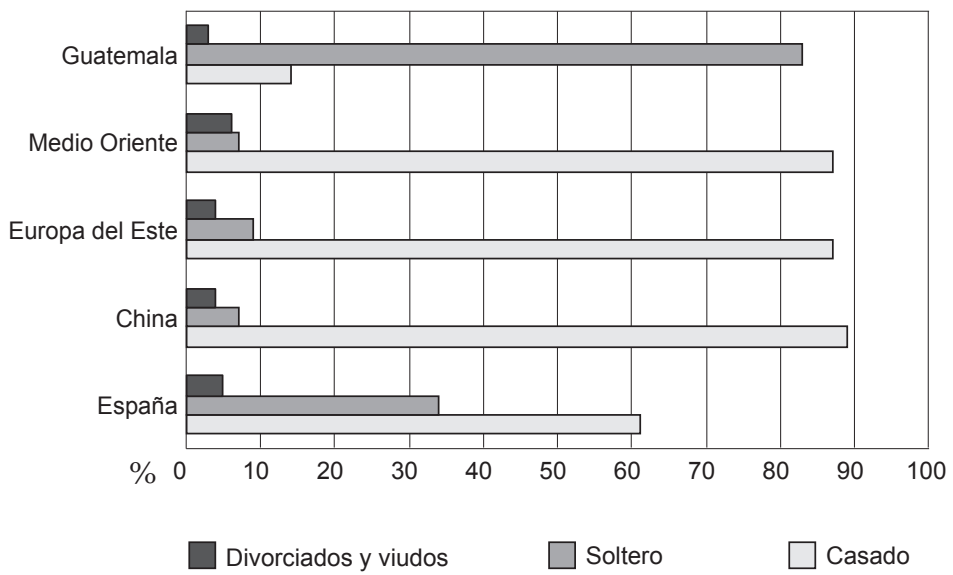

Si la naturalización fue una cuestión sobre todo masculina, habría que agregar que en su mayoría esos hombres estuvieron casados. Se carece de información para estimar el grado de endogamia comunitaria en gran número de esos matrimonios. De acuerdo con fuentes cualitativas se puede inferir que la endogamia fue elevada entre los extranjeros provenientes de Europa del Este y Medio Oriente, y que la exogamia fue dominante entre los chinos naturalizados. De cualquier modo, las altas tasas de matrimonio pondrían en evidencia que las uniones matrimoniales y sobre todo la descendencia en hijos nacidos en México fue un indicador que las autoridades utilizaron para validar residencias definitivas y en consecuencia rangos de integración a la sociedad nacional. Claro está que esa valoración seguramente dependió de los criterios 
de "asimilabilidad" que la propia autoridad asignaba a cada una de las comunidades de extranjeros; ello explica que los menos "asimilables" muestren los más altos índices de matrimonio. La correlación inversa entre extranjeros valorados como "no asimilables" y sus índices de matrimonio derivaría de la necesidad de contrarrestar la imagen negativa que pesaba sobre ellos. Un caso ejemplar es el de los chinos, con índices de matrimonio cercanos a $90 \%$, mientras que en los españoles las "afinidades étnicas" explicarían mayores otorgamientos de naturalización a hombres solteros. Por último, la peculiar manera en que se naturalizó a los guatemaltecos permitiría explicar que el estado civil no haya sido un indicador tomado en cuenta por las autoridades, toda vez que más de las dos terceras partes de los guatemaltecos eran solteros. La elevada tasa de soltería en una nacionalidad que registra una participación femenina por encima del promedio invita a pensar que los guatemaltecos fueron registrados como solteros porque vivían en unión libre o porque la indefinición de su nacionalidad impidió registrar uniones matrimoniales ante juzgados civiles.

\section{INSERCIONES LABORALES ${ }^{62}$}

Quizá no hay mejor muestra del fracaso de la utopía inmigracionista de las élites mexicanas que las ocupaciones de los

${ }^{62}$ La serie documental consultada (nota 26) registra más de 500 ocupaciones. Este universo fue tabulado en ocho grupos, a saber: comerciantes, trabajadores urbanos, trabajadores rurales, técnicos y artesanos, empresarios urbanos, empresarios rurales, profesionistas y otros. Por otra parte, esa serie presenta un marcado contraste en la información respecto a las ocupaciones de los naturalizados. Entre 1900 y 1936 no 
extranjeros naturalizados. Para el siglo xix, Erika Pani ha demostrado que un tercio de los naturalizados se dedicaba a actividades mercantiles. ${ }^{63}$ En la primera mitad del siglo $\mathrm{xx}$ el patrón ocupacional vuelve a mostrar la distancia entre el ideal de atraer inmigrantes capaces de modernizar la agricultura y la industria y una realidad que exhibe a los inmigrantes insertos en otros espacios laborarles. El europeo occidental, paradigma del extranjero deseable, disminuyó su representación en las naturalizaciones. Además, segmentos importantes de esos europeos, junto con la mayoría de los inmigrantes de orígenes nacionales nuevos, estuvieron asociados al comer-

hay información sobre ocupaciones en $2 \%$ de los naturalizados; pero este porcentaje crece a $98 \%$ para el periodo comprendido entre 1937 y 1953. La única posibilidad de completar estos datos radica en la consulta de los expedientes personales de naturalización. Sin embargo, la Ley de Archivos vigente restringe la consulta de aquellos expedientes con una antigüedad mayor a 70 años. De esta manera el año final que pudimos incluir fue 1943. Como para el conjunto del periodo 1900-1943 se conocía el total de extranjeros naturalizados por año y por la nacionalidad de origen, para el subperiodo 1900-1936, 2\% de los naturalizados sin datos se distribuyeron conforme a la proporción observada para $98 \%$ de los casos con datos. Resultó más complejo construir la serie para el subperiodo 1937-1943. El trabajo con los expedientes personales contempló un muestreo aleatorio estratificado. Para ello se consideró un tamaño de muestra de $20 \%$ del total de naturalizados por cada año con la distribución conocida de la nacionalidad de origen. La serie así construida se integró al conjunto de la serie histórica. Para el caso de los españoles, y en atención a la posibilidad de consultar la serie documental referida a naturalizaciones de refugiados republicanos (nota 27), se pudo separar a los españoles de antigua residencia de los refugiados republicanos. El muestreo se realizó conforme a la distribución anual de las naturalizaciones de españoles desagregados en uno y otro grupo.

${ }^{63}$ Pani, Para pertenecer, p. 186. 
cio, actividad que detonó las ruidosas campañas nacionalistas de los años veinte y treinta.

Entre 1900 y 1943, 38\% de los nacionalizados se dedicaron al comercio. El resto se distribuyó entre una variedad de ocupaciones que, en comparación con el siglo XIX, pone en evidencia la expansión de mercados de trabajo en las ciudades, consecuencia de un modelo económico que acusa la emergencia de nuevas actividades industriales, comerciales y de servicios. El espacio urbano atrajo extranjeros por estas razones, pero también porque el campo perdió atractivo ante una acrecentada conflictividad resultado de la revolución de 1910.

De los naturalizados, 22\% fueron técnicos, artesanos y empleados urbanos; si a éstos agregamos los dedicados al comercio se advierte que la mayoría de los mexicanos por naturalización se ubicaron en los sectores medios de la sociedad. Es posible inferir que se trata de núcleos de reciente ingreso a estos sectores, consecuencia de una cultura de trabajo y ahorro que confirió oportunidad para un relativamente rápido ascenso social desde estratos urbanos pobres en los que se ubicaron al momento de su llegada al país.

Un dato significativo es el 10\% que ocupan los profesionistas en el total de naturalizados entre 1900 y 1943, porcentaje que duplica la cifra de este sector en el siglo XIX. ${ }^{64}$ Los trabajadores rurales están ausentes en la mayoría de las nacionalidades, a excepción de los guatemaltecos. La casi totalidad de este colectivo trabajó en faenas agrícolas, rubro que representa $18 \%$ de los naturalizados. Por último, la baja representación de empresarios rurales y urbanos hace evidente que para estos grupos la búsqueda de la nacionalidad mexica-

${ }^{64}$ Pani, Para pertenecer, p. 186. 
na parece no haber sido una prioridad, a diferencia de aquellos ubicados en las capas medias de la sociedad. A pesar de esta baja representación, resulta indicativo que el empresario rural mostrara mayor disposición a naturalizarse que el urbano, consecuencia del estado de agitación que sacudía al campo mexicano, en décadas en que la amenaza de reforma agraria restaba seguridad sobre los derechos de propiedad previamente adquiridos.

Gráfica 20

NATURALIZADOS POR OCUPACIÓN, 1900-1943

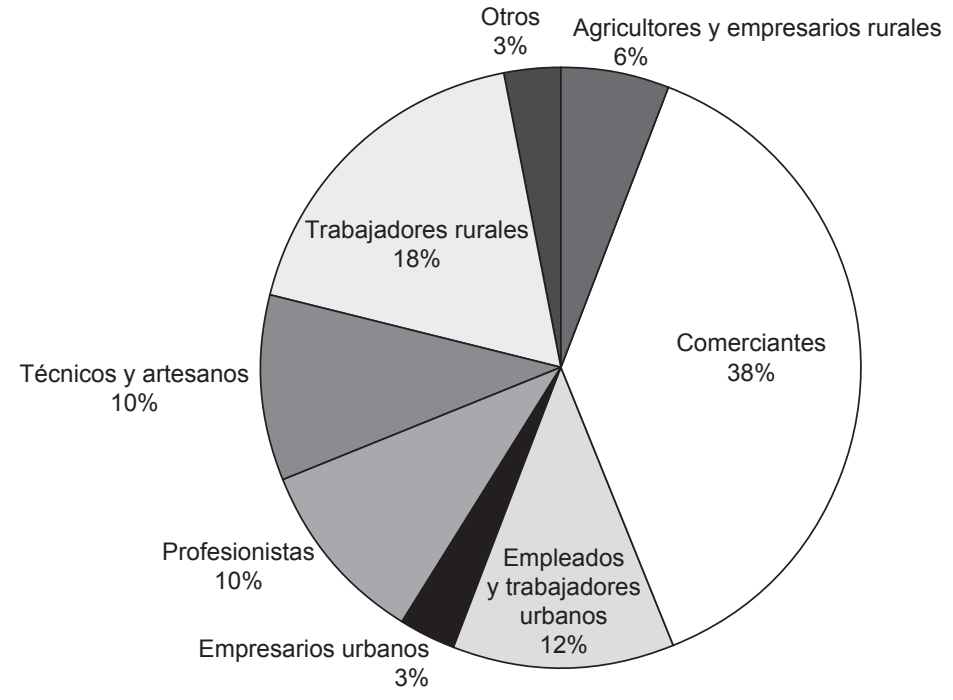

Si se discriminan las ocupaciones por comunidades de origen, se advierte que más de $80 \%$ de los chinos y de los naturales de Medio Oriente se dedicaron a actividades mercantiles, proporción que disminuye $61 \%$ en nativos de Europa del Este y llega a $40 \%$ en el caso de los españoles. Si bien 
el comercio fue la principal fuente de ingresos de los naturalizados, para el resto de las ocupaciones las diferencias son importantes. Españoles y alemanes aportaron cerca de $60 \%$ de profesionales, mientras que $17 \%$ correspondieron a los europeos del Este. Rusos, polacos, ucranianos, lituanos, etc., por lo general asociados casi exclusivamente a trabajos comerciales, fueron las nacionalidades que contribuyeron con más profesionales después de los españoles, alemanes y franceses. Como se indicó, la casi totalidad de los trabajadores agrícolas fueron guatemaltecos (98\%), mientras que los trabajadores urbanos en sus tres cuartas partes fueron europeos occidentales. A su vez, los empresarios urbanos están representados con $38 \%$ de europeos del Este y $44 \%$ de españoles, alemanes, austríacos y franceses en su mayoría. En el caso de los naturalizados propietarios de negocios agrícola ganaderos, los europeos occidentales representan $60 \%$, los estadounidenses $14 \%$ y los chinos y japoneses 13 por ciento.

La distribución anual de las ocupaciones entre 1920 y 1940 , periodo en que se registró el mayor volumen de naturalizaciones, revela las motivaciones de los solicitantes y muestra las respuestas de los gobiernos revolucionarios. El peso de los comerciantes es abrumador frente a cualquier otra actividad; por otra parte, es evidente el impacto que tuvo la norma migratoria en la política de naturalización. En las leyes de migración de 1926 y 1930, las actividades comerciales al menudeo fueron un obstáculo para la obtención de visados, y en la Ley de Población de 1936 esas actividades fueron prohibidas. En esos años, el otorgamiento de cartas de naturalización dibuja las caídas más pronunciadas, de modo que las restricciones a inmigrantes dedicados al comercio funcionaron también para aquellos que buscaban acceder a la nacionalidad a 


\section{Gráfica 21}

OCUPACIÓN DE NATURALIZADOS POR REGIÓN DE ORIGEN, $\%$ 1900-1943

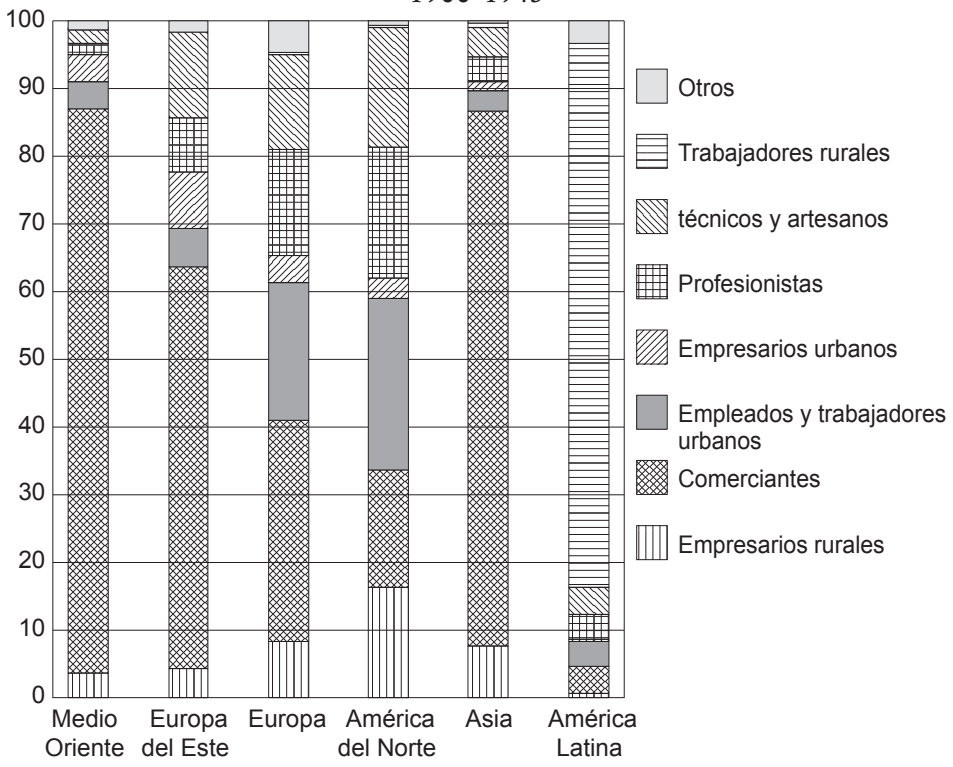

pesar de poder acreditar una larga residencia en México. Después de cada caída, el otorgamiento de cartas de nacionalidad se reactivaba debido en parte a la fuerza inercial de la actividad mayoritaria entre los solicitantes, pero probablemente también a la búsqueda de seguridades ante un clima político sacudido por reclamos y querellas contra comerciantes extranjeros. El descenso que se advierte en el último año del cardenismo no podría asociarse a una legislación en particular sino a la combinación de un ambiente marcadamente antigachupín, producto de las inclinaciones políticas de la antigua comunidad española en favor del franquismo, junto con la drástica reducción de los flujos migratorios desde comienzo de los 


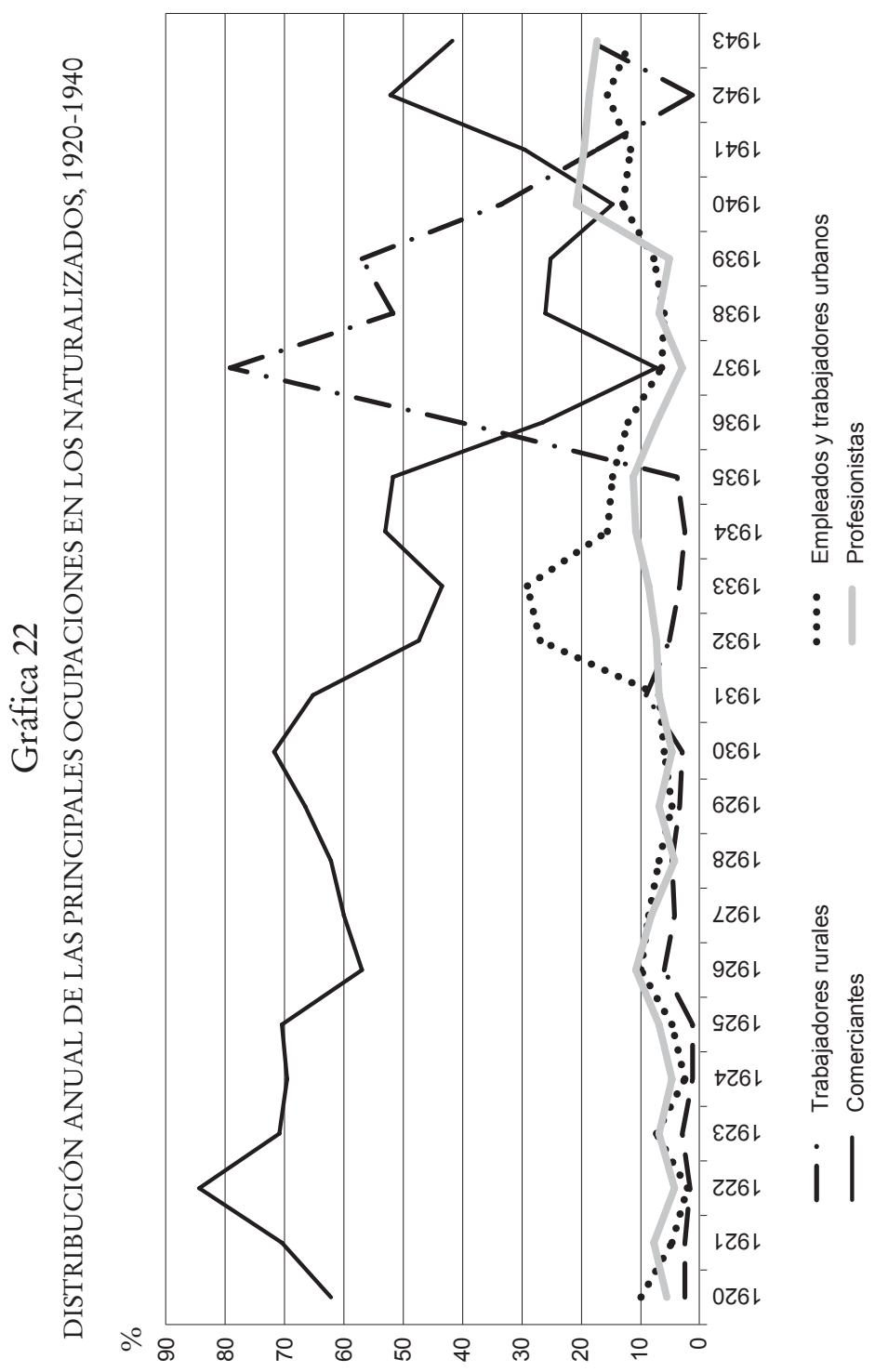


treinta y la drástica disminución de la comunidad china, resultado de las expulsiones de 1931 y 1932.

Pareciera que las naturalizaciones fueron resultado de imperativos marcados por la necesidad de permanecer en México. Las ocupaciones asociadas a la migración con mayores restricciones están fuertemente representadas en los índices de naturalización durante los años de las campañas nacionalistas. Además del comercio, figuran los empleos urbanos y el trabajo de técnicos y artesanos. A partir de 1931 se observan incrementos de naturalizados en el contexto de una recién aprobada Ley Federal del Trabajo que, como ya se indicó, estipuló el porcentaje máximo de extranjeros sobre la planta laboral que podía contratar una empresa. Buena parte de las empresas comerciales e industriales de inmigrantes eran negocios familiares, de modo que la opción de la naturalización garantizaba la continuidad de estas fuentes de empleo amenazadas por una legislación ideada para obligar a la contratación de mexicanos.

En la década de los treinta, signada por fuertes contracciones de los mercados laborales, destaca la expansión del empleo agrícola entre los naturalizados. Este paradójico fenómeno está directamente asociado a los guatemaltecos en Chiapas. Por último, el incremento de los profesionistas a partir de finales de los años treinta revela el impacto de los refugiados españoles. Entre 1940 y 1943, 35\% de los refugiados naturalizados fueron profesionales, cantidad que contrasta con $7 \%$ de profesionales de la antigua colonia española. Los refugiados republicanos incidieron también en los índices de naturalización de empleados y técnicos urbanos, y en indicadores de trabajos asociados a mujeres, quienes además de las labores domésticas, aparecen vinculadas al ejercicio de actividades artísticas, la docencia y el empleo en el sector de servicios. 


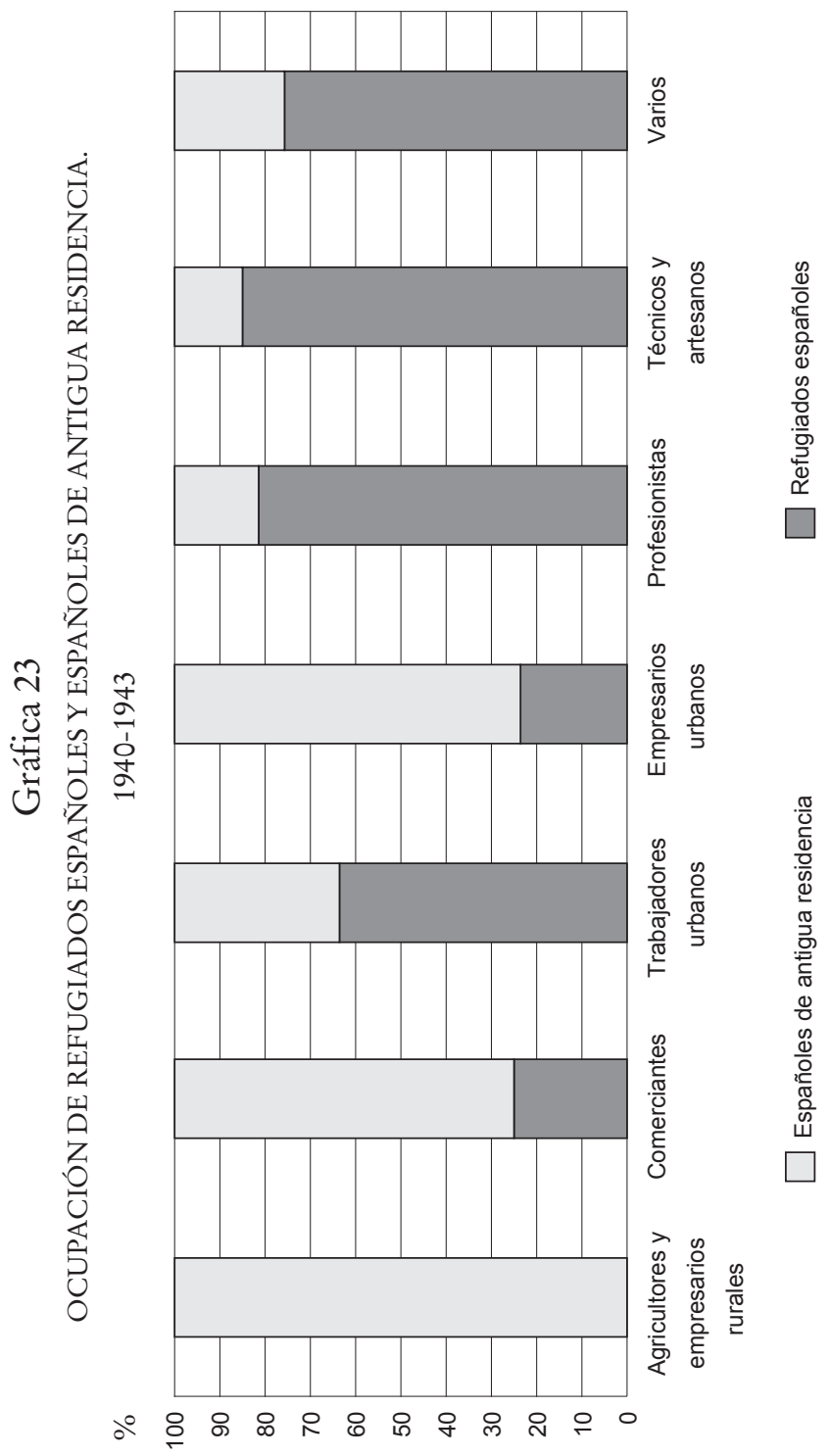


Los bajos índices de naturalización de extranjeros en México pueden interpretarse como resultado del escaso atractivo que la nacionalidad mexicana tuvo para las comunidades de extranjeros, o como consecuencia de una política estatal poco interesada en ensanchar los límites políticos de la nación. Es posible que la explicación radique en la convergencia de ambas razones. La nacionalidad mexicana fue atractiva sólo para algunas comunidades de inmigrantes, y además las comunidades que con más ahínco buscaron naturalizarse fueron aquellas que despertaron más recelos en las autoridades.

La reconstrucción de la serie completa de naturalizaciones en la primera mitad del siglo xx exhibe el impacto de dos decisiones políticas excepcionales: la regularización de poblaciones rurales de origen guatemalteco con residencia en Chiapas y el refugio a los republicanos españoles. La voluntad de convertir en mexicanos a más de 4000 guatemaltecos y a 2500 republicanos tuvo una fuerte incidencia en los volúmenes y en los perfiles sociodemográficos de los naturalizados. El caso de los guatemaltecos concentra la casi totalidad de naturalizados dedicados al trabajo agrícola, y además la excepcionalidad de este caso radica en que se trata de naturalizaciones que en su mayoría involucran a integrantes de comunidades indígenas. A finales del siglo xx, es posible localizar un proceso similar, cuando una vez cerrado el ciclo de la guerra civil en Guatemala, y en el marco del retorno de los refugiados guatemaltecos en México, el gobierno nacional abrió la puerta a la naturalización para los exrefugiados que decidieron permanecer en el país. De nueva cuenta, se trató de una política oficial como la llevada a cabo por la CDI en los años treinta, aunque 
en este caso dirigida a contingentes de hombres y mujeres que arribaron al país en particulares condiciones de persecución política y étnica. ${ }^{65}$ Los republicanos españoles también fueron perseguidos, de esta manera, por la vía de la solidaridad política se naturalizó a un universo de europeos cuyos perfiles ocupacionales ensancharon espacios como el de los profesionales, que en lo general eran poco frecuentados por los solicitantes de la nacionalidad mexicana.

Al margen de estas dos comunidades, en la experiencia de naturalización en la primera mitad del siglo xx se advierte un patrón de cuño decimonónico acrecentado por la política nacionalista resultado de la revolución de 1910. Es decir, para aproximarse a las coordenadas que imprimieron sentido a las solicitudes y a las concesiones de la nacionalidad mexicana es necesario tomar en cuenta el peso de un sistema normativo que en el ámbito constitucional y de la legislación secundaria acotó derechos de propiedad y de empleo a los extranjeros, al tiempo que restringió derechos ciudadanos a los extranjeros naturalizados. De ahí la simetría entre coyunturas de marcadas restricciones a la presencia extranjera y el incremento de las naturalizaciones. La búsqueda de la nacionalidad mexicana parece responder a la necesidad de asegurar derechos de residencia y de trabajo amenazados por fuertes campañas nacionalistas. Se puede conjeturar que esta fue una conducta seguida por algunas comunidades de inmigrantes, fundamentalmente aquellas que advertían la imposibilidad de encontrar protección en los gobiernos de sus naciones de origen. No fue así con estadounidenses, ingleses, franceses y alemanes, cuyos índices de naturalización disminuyeron de manera

${ }^{65}$ Véanse Kauffer Michel (comp.), La integración y Comar, Memoria. 
drástica en comparación con lo ocurrido en el siglo xix; además, claro está, porque esas comunidades redujeron su participación en el conjunto de la inmigración en México. Frente a estos casos, se asiste a un incremento de las naturalizaciones de otras comunidades: asiáticos, europeos orientales e inmigrantes de Medio Oriente. Para estos inmigrantes el recurso de la naturalización atendió tanto a restricciones a las actividades comerciales que desarrollaron mayoritariamente, como a exclusiones étnicas en el entendido de que su presencia fue valorada como una amenaza a la salud de una nación que bregaba por imponer una homogeneidad mestiza. En este sentido, la obtención de la nacionalidad otorgaba seguridades laborales, y además abría la posibilidad de gestionar el ingreso de familiares a quienes se negaban visados en atención a las restricciones migratorias.

La defensa del mestizaje supuestamente debió favorecer las naturalizaciones de españoles; sin embargo, a la luz de la excepcional situación que inauguran los refugiados republicanos, se advierte que la vía del privilegio sancionada para ellos fue usada profusamente por los antiguos residentes españoles. Esta evidencia permite inferir que la obtención de la nacionalidad mexicana no debió ser fácil para esos españoles. Sobre ellos pesaba una densa memoria de agravios de raigambre colonial que desequilibraba las ventajas y deseabilidad que las propias autoridades encontraban en esta inmigración.

En resumen, la solicitud de la nacionalidad por un lado y su concesión por otro, poco tuvo que ver con ampliar la participación y representación de la nación en tanto sujeto político. Los derechos ciudadanos no están presentes en las expectativas de quienes piden y de quienes otorgan la nacionalidad mexicana. Para los primeros se trató de un actuar 
pragmático interesado en resolver maneras de ganarse la vida, mientras que en el ámbito de las autoridades se podría inferir que la concesión de la nacionalidad fue más resultado de percepciones alrededor de una extranjería por lo general valorada como una amenaza que de decisiones fundadas en una racionalidad económica y política. Es decir, se trató de decisiones impregnadas de tal arbitrariedad que así como benefició a guatemaltecos y republicanos españoles, también convirtió en mexicanos a un creciente número de inmigrantes indeseables.

\section{SIGLAS Y REFERENCIAS}

AHDSRE Archivo Histórico Diplomático. Secretaría de Relaciones Exteriores, México.

AHINM Archivo Histórico del Instituto Nacional de Migración, México.

CILA Comisión Internacional de Límites y Aguas entre México y los Estados Unidos.

COMAR Comisión Mexicana de Ayuda a los Refugiados, México.

INM Instituto Nacional de Migración, México.

SRE Secretaría de Relaciones Exteriores, México.

Aboites Aguilar, Luis

Norte precario. Poblamiento y colonización en México, 17601940, México, El Colegio de México, Centro de Investigaciones y Estudios Superiores en Antropología Social, 1995.

Alanís Enciso, Fernando Saúl

Que se queden allá. El gobierno de México y la repatriación de mexicanos de Estados Unidos 1934-1940, México, El Colegio de la Frontera Norte, El Colegio de San Luis, 2007.

Alfaro-Velcamp, Theresa

"When Pernicious Foreigners Become Citizens: Naturaliza- 
tion in Early Twentieth-Century Mexico", en Journal of Politics and Law, 6:1 (2013), pp. 46-63.

Antiq-Auvaro, Raymonde

L'Émigration des barcelonnettes au Mexique, Niza, Serre, 1992.

Balderrama E., Francisco y Raymond Rodríguez

Decade of Betrayal. Mexicans Repatriated in the 1930s, Nuevo Mexico, University of New Mexico Press, 1995.

Benjamin, Thomas

A Rich Land, A Poor People. Politics and Society in Modern Chiapas, Albuquerque, University of New México Press, 1989.

Bernecker, Walther L.

Alemania y México en el siglo XIX, México, Universidad Nacional Autónoma de México, El Colegio de México, 2005.

Berninger, Dieter G.

La inmigración en México, 1821-1857, México, Secretaría de Educación Pública, 1974.

Cámara de Diputados

Los derechos del pueblo mexicano: México a través de sus constituciones, México, Cámara de Diputados, Miguel Ángel Porrúa, 2000, t. v.

Carrillo, Jorge Aurelio

"La postura de la Constitución Mexicana frente a los problemas de nacionalidad", en Revista de la Facultad de Derecho, 54 (abr.-jun. 1964), pp. 389-408.

Castillo, Manuel Ángel

“Extranjeros en México, 2000-2010”, en Coyuntura Demográfica, 2 (2012), pp. 57-61. 
Castillo, Miguel Ángel, Mónica Toussaint y Mario Vázquez

Espacios diversos, historia en común. México, Guatemala y Belice: la construcción de una frontera, México, Secretaría de Relaciones Exteriores, 2006.

Castillo, Manuel Ángel y Mario Vázquez Olivera

"Los inmigrantes guatemaltecos en México. Antecedentes históricos y situación actual”, en Rodríguez Chávez (coord.), 2010, pp. 237-274.

Censos

Censos Generales de Población.

Chao Romero, Robert

The Chinese in Mexico (1882-1940), Arizona, The University of Arizona Press, 2010.

Constitución

Constitución Política de los Estados Unidos Mexicanos, México, Dirección General de Educación Pública, 1917.

Dávila Valdés, Claudia

Refugiados españoles en Francia y México. Un estudio comparativo, México, El Colegio de México, 2012.

Diario de Debates

Diario de Debates del Congreso Constituyente de Querétaro, edición a cargo de Ignacio Marván, México, Suprema Corte de Justicia de la Nación, 2007.

Durán Ochoa, Jorge

Estructura económica y social de México. Población, México, Fondo de Cultura Económica, 1955.

Freeman Smith, Robert

The United States and Revolucionary Nationalism in México, 1916-1932, Chicago, The University of Chicago Press, 1972. 
Gamboa Ojeda, Leticia (coord.)

Los barcelonnettes en México, miradas regionales, siglos XIX$X X$, Puebla, Benemérita Universidad Autónoma de Puebla, 2008.

Gerardo Pérez, Sandra O.

"Nacionalidad, trabajo y tierra. Relación histórica en una región fronteriza. El Soconusco y el Estado mexicano en la década del treinta del siglo xx", tesis de licenciatura en historia, México, Universidad Nacional Autónoma de México, 2013.

Gil Lázaro, Alicia

"La presencia de españoles en México en el siglo xx (19101980)”, en Rodríguez Chávez (coord.), 2010, pp. 133-172.

Gleizer, Daniela

"Los límites de la nación. Naturalización y exclusión en el México posrevolucionario”, en Gleizer y López CaballeRO (coords.) [en prensa].

Gleizer, Daniela y Paula López Caballero (coords.)

Mestizos, indígenas y extranjeros. Nuevas miradas sobre nación y alteridad en México, México, Universidad Autónoma Metropolitana, Ediciones de Educación y Cultura [en prensa].

Gojman de Backal, Alicia

Camisas, escudos y desfiles militares. Los Dorados y el antisemitismo en México, México, Universidad Nacional Autónoma de México, Fondo de Cultura Económica, 2000.

González Navarro, Moisés

Los extranjeros en México y los mexicanos en el extranjero, México, El Colegio de México, 1996.

Gouy, Patrice

Pérégrinations des barcelonettes an Mexique, Grenoble, Presses Universitaires de Grenoble, 1980. 
Grageda Bustamente, Aarón (coord.)

Seis expulsiones y un adiós: despojos y exclusiones en Sonora, México, Universidad de Sonora, Plaza y Valdés, 2003.

Henderson, Timothy J.

Beyond Borders: A History of Mexican Migration to the United States, Reino Unido, Wiley-Blackwell, 2011.

Herrera Barreda, María del Socorro

Inmigrantes hispano-cubanos en México durante el porfiriato, México, Universidad Autónoma Metropolitana, Miguel Ángel Porrúa, 2003.

Illades, Carlos

Presencia española en la Revolución Mexicana (1910-1915), México, Universidad Nacional Autónoma de México, Instituto de Investigaciones Dr. José María Luis Mora, 1991.

Instituto Nacional de Migración

Compilación histórica de la legislación migratoria en México, 1821-2002, México, Instituto Nacional de Migración, 2002.

Kauffer Michel, Edith F. (comp.)

La integración de los exrefugiados guatemaltecos en México: una experiencia con rostros múltiples, San Cristóbal de Las Casas, Chiapas, El Colegio de la Frontera Sur, 2002.

Knight, Alan

"Nationalism, Xenophobia and Revolution. The Place of Foreigners and Foreign Interest in México 1910-1915”, tesis de doctorado, Oxford, Oxford University, 1974.

Lida, Clara E.

Inmigración y exilio. Reflexiones sobre el caso español, México, El Colegio de México, Siglo Veintiuno Editores, 1997.

"Los españoles en México: de la Guerra Civil al franquismo, 1939-1950”, en Lida (comp.), 2001, pp. 203-252. 
LidA, Clara E. (comp.)

Una inmigración privilegiada: los españoles en México, Madrid, Alianza, 1994.

México y España en el primer franquismo, 1939-1950. Rupturas formales, relaciones oficiosas, México, El Colegio de México, 2001.

Loyo, Gilberto

La política demográfica de México, México, Partido Nacional Revolucionario, 1935.

Martínez Assad, Carlos (ed.)

La ciudad cosmopolita de los inmigrantes, México, Gobierno del Distrito Federal, 2010, 2 volúmenes.

Martínez Rodríguez, Marcela

Colonizzazione al Messico! Las colonias agrícolas de italianos en México, 1881-1910, México, El Colegio de Michoacán, El Colegio de San Luis, 2013.

Martínez Velasco, Germán

Plantaciones, trabajo guatemalteco y política migratoria en la frontera sur de México, México, Instituto Chiapaneco de Cultura, 1994.

Memoria

Memoria. Presencia de los refugiados guatemaltecos en México, México, Alto Comisionado de las Naciones Unidas para los Refugiados, Fondo de Cultura Económica, Comisión Mexicana de Ayuda a Refugiados, 1999.

Mentz, Brígida von et al.

Los pioneros del imperialismo alemán en México, México, Centro de Investigaciones y Estudios Superiores en Antropología Social, 1982. 
Meyer, Jean

"Los franceses en México durante el siglo xix", en Relaciones, 2 (1980), pp. 5-54.

Meyer, Rosa María y Delia Salazar (coords.)

Los inmigrantes en el mundo de los negocios, México, Instituto Nacional de Antropología e Historia, 2003.

Overmyer-Velazquez, Mark (ed.)

Beyond la Frontera: The History of Mexico-U.S. Migration, Oxford, Oxford University Press, 2011.

PANi, Erika

"Hacer propio lo que es ajeno. Políticas de naturalización en América del Norte, Estados Unidos y México, siglo xix”, en Revista de Indias, 72 (255) (2012), pp. 349-366.

"Ciudadanos precarios. Naturalización y extranjería en el México decimonónico”, en Historia Mexicana, 62:2 (246) (oct.-dic. 2012), pp. 627-674.

Para pertenecer a la gran familia mexicana: procesos de naturalización en el siglo XIX, México, El Colegio de México [en prensa].

Pérez Montfort, Ricardo

Por la patria y por la raza. La derecha secular en el sexenio de Lázaro Cárdenas, México, Universidad Nacional Autónoma de México, 1993.

Pérez Vejo, Tomás

"España en el imaginario mexicano: el choque del exilio", en Sánchez Andrés y Figueroa Zamudio (coords.), 2001, pp. 23-93.

Pla Brugat, Dolores

“Españoles en México (1895-1980). Un recuento”, en Secuencia, 24 (1992), pp. 107-120. 
Proal, Maurice y Pierre Martin Charpenel

L'Empire des Barcelonnettes an Mexique, Marseille, J. Laffitte, 1986.

Puig, Juan

Entre el río Perla y el Nazas. La China decimonónica y sus braceros emigrantes, la colonia china de Torreón y la matanza de 1911, México, Consejo Nacional para la Cultura y las Artes, 1992.

ReÑIQUe, Gerardo

"Región, raza y nación en el antichinismo sonorense. Cultura regional y mestizaje en el México posrevolucionario”, en GRAgeda Bustamente (coord.), 2003, pp. 231-289.

Reyes Ramos, María Eugenia

El reparto de tierras y la política agraria en Chiapas, 19141988, México, Universidad Nacional Autónoma de México, 1992.

Rodríguez Chávez, Ernesto

"Fuentes de información estadística sobre los inmigrantes en México”, en Rodríguez Chávez (coord.), 2010, pp. 21-49.

Rodríguez Chávez, Ernesto (coord.)

Extranjeros en México. Continuidades y aproximaciones, México, Instituto Nacional de Migración, DGE Ediciones, 2010.

Rodríguez Kuri, Ariel (coord.)

Historia política de la ciudad de México (desde su fundación hasta el año 2000), México, El Colegio de México, 2010.

Salazar, Delia

Las cuentas de los sueños. La presencia extranjera en México a través de las estadísticas nacionales, 1880-1914, México, Instituto Nacional de Antropología e Historia, DGE Ediciones, 2010. 
Sánchez Andrés, Agustín y Silvia Figueroa Zamudio (coords.)

De Madrid a México. El exilio español y su impacto sobre el pensamiento, la ciencia y el sistema educativo mexicano, Madrid, Universidad Michoacana, Comunidad de Madrid, 2001.

Skerritt Gardner, David

Colonos franceses y modernización en el Golfo de México, México, Universidad Veracruzana, 1995.

Viqueira, Juan Pedro y Mario Humberto Ruz (eds.)

Chiapas. Los rumbos de otra historia, México, Universidad Nacional Autónoma de México, Centro de Investigaciones y Estudios Superiores en Antropología Social, 1995.

Vos, Jan de

Las fronteras de la frontera sur: reseña de los proyectos de expansión que figuraron la frontera entre México y Centroamérica, México, Universidad Autónoma de Tabasco, Centro de Investigaciones y Estudios Superiores en Antropología Social, 1993.

\section{Yankelevich, Pablo}

"Hispanofobia y Revolución. La política de expulsión de españoles en México (1911-1940)", en The Hispanic American Historical Review, 86 (2006), pp. 29-59.

"Gringos Not Wanted", en Aztlán, Journal of Chicano Studies, 34:1 (2009).

$¿$ Deseables o inconvenientes? Las fronteras de la extranjería en el México posrevolucionario, México, Madrid, Escuela Nacional de Antropología e Historia, Bonilla Artigas, Iberoamericana, Vervuert, 2011. 
